\title{
Catalytic Destruction of Hazardous Organics in Aqueous Solutions
}

\author{
E. G. Baker \\ L. J. Sealock, Jr.
}

April 1988

Prepared for the U.S. Department of Energy under Contract DE-AC06-76RLO 1830

Pacific Northwest Laboratory

Operated for the U.S. Department of Energy

by Battelle Memorial Institute 


\title{
DISCLAIMER
}

This report was prepared as an account of work sponsored by an agency of the United States Government. Neither the United States Government nor any agency thereof, nor Battelle Mernorial Institute, nor any or their employees, makes any warranty, expressed or implied, or assumes any legal liability or responsibility for the accuracy, completeness, or usefulness of any information, apparatus, product, or process disclosed, or represents that its use would not infringe privately owned rights. Reference herein to any specific commercial product, process, or service by trade name, trademark, manufacturer, or otherwise does not necessarily constitute or imply its endorsement, recommendation, or favoring by the United States Government or any agency thereof, or Battelle Memorial Institute. The views and opinions of authors expressed herein do not necessarily state or reflect those of the United States Government or any agency thereof, or Battelle Memorial Institute.

\author{
PACIFIC NORTHWEST LABORATORY \\ operated by \\ BATTELLE MEMORIAL INSTITUTE \\ for the \\ UNITED STATES DEPARTMENT OF ENERGY \\ under Contract DE-ACO6-76RLO 1830
}

\begin{tabular}{|c|c|}
\hline \multicolumn{2}{|c|}{ Printed in the United States of America } \\
\hline \multicolumn{2}{|c|}{ Available from } \\
\hline \multirow{2}{*}{\multicolumn{2}{|c|}{$\begin{array}{l}\text { National Technical Information Service } \\
\text { United States Department of Commerce }\end{array}$}} \\
\hline & \\
\hline \multicolumn{2}{|c|}{5285 Port Royal Road } \\
\hline \multicolumn{2}{|c|}{ Springfield, Virginia 22161} \\
\hline \multirow{2}{*}{\multicolumn{2}{|c|}{$\begin{array}{l}\text { NTIS Price Codes } \\
\text { Microfiche A01 }\end{array}$}} \\
\hline & \\
\hline \multicolumn{2}{|c|}{ Printed Copy } \\
\hline & Price \\
\hline Pages & Codes \\
\hline 001-025 & $\mathrm{A} 02$ \\
\hline 026-050 & $\mathrm{A03}$ \\
\hline 051-075 & A04 \\
\hline 076-100 & A05 \\
\hline $101-125$ & $\mathrm{~A} 06$ \\
\hline $126-150$ & A07 \\
\hline 151-175 & A08 \\
\hline $176-200$ & A09 \\
\hline 201-225 & A010 \\
\hline $226-250$ & A011 \\
\hline $251-275$ & A012 \\
\hline $276-300$ & A013 \\
\hline
\end{tabular}


PNL-6491-2

UC -69

CATALYTIC DESTRUCTION OF HAZARDOUS

ORGANICS IN AQUEOUS SOLUTIONS

E. G. Baker

L. J. Sealock, Jr.

April 1988

Prepared for the U.S. Department of Energy

under Contract DE-ACO6-76RLO-1830

Pacific Northwest Laboratory

Richland, Washington 99352 


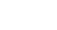




\section{SUMMARY}

Pacific Northwest Laboratory (PNL) is developing a process for destroying hazardous organics and chlorinated organics in aqueous solutions. The process is targeted at liquid waste streams that are difficult and costly to treat with conventional or developing technologies. Examples of these waste streams include contaminated groundwater and surface water and industrial was tewater.

In the PNL process, aqueous solutions are treated with a transition metal catalyst at $300^{\circ} \mathrm{C}$ to $460^{\circ} \mathrm{C}$ and 2000 to $5000 \mathrm{psig}$ pressure to convert the wastes to innocuous gases. During proof-of-principle tests conducted in a 1-L batch reactor, destruction of over 99\% (in most cases approaching $99.9 \%$ ) of the organic material was achieved. Hexone (methyl isobutyl ketone, MIBK), p-cresol, hexane, benzene, and naphthalene were used as model waste materials. The only major product with all of the organic compounds was a gas containing $50 \%$ to $75 \%$ methane, $25 \%$ to $45 \%$ carbon dioxide, and $0 \%$ to $5 \%$ hydrogen.

A variety of catalysts and experimental conditions were used in the proof-of-principle tests. These tests showed that reduced nickel was the only effective catalyst and that the optimal operating conditions for destroying nonchlorinated organics were $350^{\circ} \mathrm{C}$ to $400^{\circ} \mathrm{C}, 2000$ to $4000 \mathrm{psig}$, and 30- to 60-min residence time. These tests also indicated that catalyst deactivation or fouling would not be a problen at these conditions.

Two chlorinated hydrocarbons, chlorobenzene and trichloroethylene (TCE), were also tested. Destruction of both compounds was $99 \%$ or greater, but the products were different from those obtained from hydrocarbons. With TCE, the major product was carbon dioxide; with chlorobenzene the major product identified was benzene. In the tests with the chlorinated hydrocarbons, the chlorine was converted to $\mathrm{HCl}$ and the reduced nickel was converted to nickel hydroxide, which may be detrimental to long-term catalyst activity.

The first 6 months of testing in the batch reactor have indicated that the concept has significant promise as a commercial process for destroying hazardous organics and chlorinated organics in aqueous streams. The major 
benefit of catalytic destruction, compared with conventional treatment technology such as carbon adsorption or air stripping, is that the process removes and destroys the organic materials. No hazardous residuals are produced. A gas, which can be burned for process heat, and a clean water stream are the only products. The process is adaptable to modular construction for mobile units, and can be used to treat a wide range of organic compositions and concentrations. An invention report on the concept has been filed, and a review of the relevant literature completed. A patent application was filed in March 1988.

Additional testing with a continuous flow reactor is needed to determine the effect of pressure and flow rate (residence time) on destruction. In addition, better analytical techniques are required to study more dilute solutions and provide improved material balances with the chlorinated hydrocarbons. When this information is obtained, a preliminary design and economic feasibility study can be completed. Based on favorable results, a transportable demonstration unit could be built, and the concept could be field tested as early as 1989. 


\section{ACKNOWLEDGMENTS}

This work was performed by Pacific Northwest Laboratory (PNL) for the U.S. Department of Energy (DOE) under funding provided by the Northwest Hazardous Waste Research, Development, and Demonstration Center, as part of the Waste Treatment Technology Task. The support of J. N. Hartley and T. L. Stewart of the Center is gratefully acknowledged.

We also wish to acknowledge K. E. Hartz for his assistance in the selection and evaluation of hazardous wastes used for study in the project. We would like to thank D. C. Elliott for his contribution to developing the initial concept and his continued support and suggestions. We would also like to thank G. G. Neuenschwander, W. F. Riemath, and G. L. Roberts for their conscientious effort in operation of the experimental and analytical systems.

The research described in this report is based on previous research on biomass gasification funded by the Biomass and Municipal Waste Technology Division (BMWTD) of DOE through the Biomass Program Office at PNL. We thank M. A. Gerber and G. F. Schiefelbein for use of the batch and continuous reactor systems, which were constructed with funding from the BMWTD. 


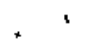

+ 


\section{CONTENTS}

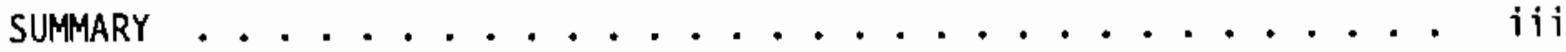

ACKNOHLEDGMENTS ....................

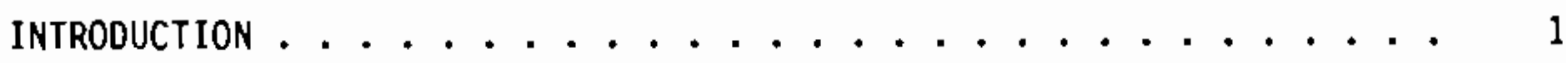

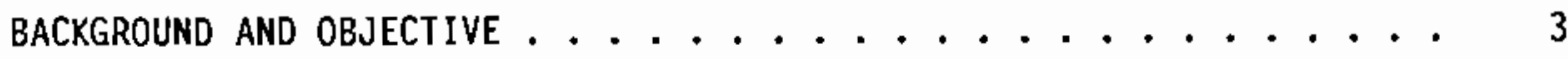

EXPERIMENTAL SYSTEM AND PROCEDURES . . . . . . . . . . 7

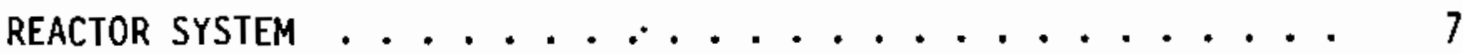

EXPERIMENTAL PROCEDURES .......................... 10

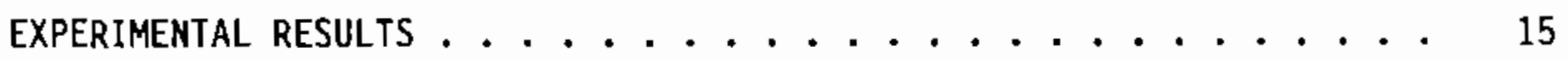

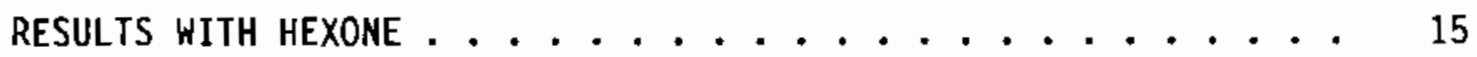

Catalyst Effect .................... 15

Effect of Temperature ............. 18

Effect of Organic Concentration ......... 20

TESTS WITH OTHER HYOROCARBONS ............... 21

RESULTS WITH CHLORINATED HYOROCARBONS ............ 22

REACTION MECHANISM ...................... 24

CONCLUSIONS AND PLAN FOR FUTURE DEVELOPMENT . . . . . . . . 27

REFERENCES .......................... 31

APPENDIX - RUN SUMMARIES ................ A.1 


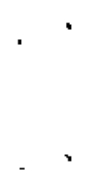

,

. 


\section{FIGURES}

1 Approximate Range of Organic Concentrations Over Which Various

Treatment Technologies are Applicable ............ 4

2 One-liter Autoclave Reactor ............... 8

3 Reactor System ..................... . . 9

4 Effect of Catalyst Loading on Carbon Conversion to Gas . . . . 17

5 Effect of Temperature on Carbon Conversion to Gas . . . . . . . 19

6 Effect of Organic Concentration on Carbon Conversion to Gas . . . 20

7 Carbon Conversion to Gas for Other Hydrocarbons . . . . . . . . 22

8 Flow Schematic of Conceptual Process . . . . . . . . . . 28

\section{$\underline{\text { IABLES }}$}

1 Properties of Organic Compounds Used in the Investigation . . . . 11

2 Physical Data for Catalysts Tested for the Destruction of

Organics in Aqueous Solutions .............. 12

3 Typical Composition of Gas Produced from Hexone with Reduced Nickel Catalysts at $400^{\circ} \mathrm{C}$. . . . . . . . . . 16

4 Hexone Conversion with Different Catalysts . . . . . . . . 16

5 Carbon on $\mathrm{Ni} 1404$ Used in Tests with Hexone .......... 18

6 Conversion of Other Hydrocarbons . . . . . . . . . . 21

7 Effect of Operating Conditions on the Enthalpy and Specific Volume of Water.................. 28 


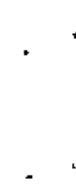




\section{INTRODUCTION}

The Northwest Hazardous Waste Research, Development, and Demonstration Center was established at Pacific Northwest Laboratory (PNL) (a) in accordance with the provisions of the Superfund Amendments and Reauthorization Act (SARA) that was signed into law by the President in October 1986. The purpose of the Center is to carry out a progran of research to adapt and develop innovative technologies for assessing the impacts of inactive hazardous and radioactive mixed-waste sites and remediating the effects of these wastes.

A multiyear research program was developed by the Center specifically to suit the needs of both the Northwest region and the Hanford Site. As part of this research program, PNL is developing a proprietary process for the catalytic destruction of hazardous organics in aqueous solutions. The process is targeted at liquid waste streams that are difficult or costly to treat with conventional or developing technologies. Specific examples of these waste streams are contaminated groundwater and surface water and industrial wastewater.

Contaminated groundwater is a problem associated with nearly all Northwest National Priorities List sites, and is an issue at most Comprehensive Environmental Response, Compensation, and Liability Information System (CERCLIS) sites in the four Northwest states and at the Hanford Site. Typical organic contaminants in groundwater include chlorinated and nonchlorinated aliphatics and aromatics.

Current technologies for treating groundwater contaminated with organics rely on separation processes, which do not destroy the hazardous material. A cost-effective method for destroying mixtures of organic compounds present at dilute concentrations in aqueous streams is needed to permanently protect human health and natural resources, as encouraged by the SARA legislation.

This report presents the results of proof-of-principle tests conducted in a $1-L$ batch reactor to evaluate the catalytic destruction process. The

(a) Operated for the U.S. Department of Energy by Battelle Memorial Institute. 
objectives of the proof-of-principle tests were to determine what types of organic materials could be destroyed and to identify the optimal operating conditions and catalysts. Model compounds were used to represent organic and chlorinated organic wastes. The results of these proof-of-principle tests can be used as a basis for further development of the process. Sunmaries of the experimental results are included in the appendix. 


\section{BACXGROUND AND OBJECTIVE}

The increasing need for cost-effective, environmentally acceptable methods for hazardous waste treatment requires that new and improved technologies be developed. A proprietary concept has been defined at PNL that has significant potential for catalytically converting organics (including chlorinated hydrocarbons) in aqueous solutions to innocuous gases. The concept was formuTated from past experience at PNL regarding high-moisture biomass gasification and catalyst research. The objective of the research project described in this report was to adapt the concept to catalytic destruction of aqueous organic hazardous waste.

Many hazardous wastes can be chemically converted to less hazardous products. Examples of some of the technologies that can be used for some types of hazardous waste include wet air oxidation, ozonation, molten salt combustion, electrochemical oxidation, neutralization, catalytic hydrogenation, and incineration. Each technology has advantages and drawbacks based on the type of waste to be treated, the concentration of the waste, specific costs, and environmental issues. Treatment of aqueous streams for organic removal is already practiced commercially, and similar processes may likely be applicable to hazardous organic waste streams.

Liquid waste streams with high organic content can be incinerated or treated with techniques using solvent extraction. Liquid streams of intermediate organic content $(0.1 \%$ to $10 \%)$ and sludges typically release much of the emissions at hazardous waste management facilities and are the most difficult wastes to treat (Allen and Blaney 1985). Aqueous streams having low organic content $(<1000 \mathrm{ppm})$ can be treated with techniques used in purifying drinking water (Love et al, 1984) or in municipal wastewater treatment (Shukla and Hicks 1984). The technologies already being used to clean leachate at large disposal sites (0'Brian and Bright 1983; Parmele and Allen 1983) rely on separation processes, such as air stripping or carbon adsorption. However, organics removed by these processes are not destroyed and are ultimately released back to the environment from off gas during air stripping and from solid wastes generated by activated carbon. 
Figure 1 shows organic concentration ranges over which various treatment technologies are applicable (Allen and Blaney 1985) and the range of treatment expected for the process being developed at PNL. The concept employs a metal catalyst to convert aqueous waste at $300^{\circ} \mathrm{C}$ to $460^{\circ} \mathrm{C}$ and high pressures up to 5000 psig. The organics are converted to innocuous gases, primarily $\mathrm{CH}_{4}, \mathrm{H}_{2}$, and $\mathrm{CO}_{2}$. The large water content of aqueous organic wastes dictates that the system operate at conditions where the water remains a liquid to prevent large expenditures of energy for water evaporation.

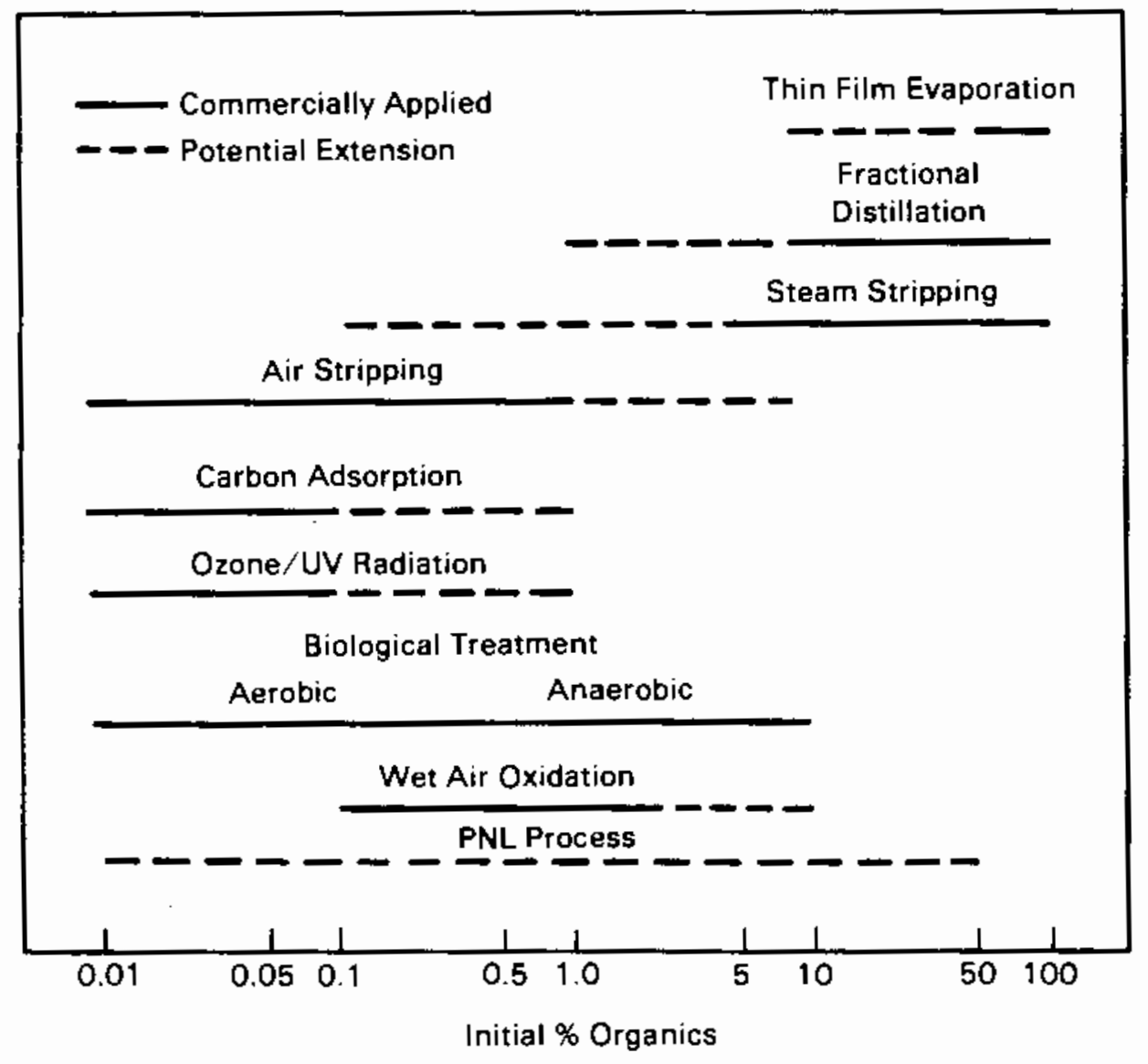

FIGURE 1. Approximate Range of Organic Concentrations Over which Various Treatment Technologies are Applicable 
A somewhat similar process (Elliott and Sealock 1982; Sealock and Elliott 1984) has been demonstrated successfully at PNL with high-moisture biomass feedstocks (up to $90 \%$ water, $10 \%$ biomass). Very high conversion of biomass to gas has been achieved at $400^{\circ} \mathrm{C}$ with nickel and nickel/alkali catalysts. Typically, 95\% carbon conversions (or higher) have been obtained for several different high-moisture feedstocks. The high pressure prevents excessive vaporization of water, which minimizes the energy requirements of the process. In many cases, the heat for catalytic destruction using this process could be supplied by burning the of $f$ gas from the system.

The purpose of the research project discussed here was to conduct proofof-principle tests with aqueous organic wastes. The objectives were to determine what types of hydrocarbons and chlorinated hydrocarbons could be destroyed and to identify the best operating conditions, i.e., type of catalyst, temperature, residence time. The information gained in the research on this process has been used to define patentable concepts for not only the catalytic destruction of aqueous organic wastes but for other destruction/ conversion applications as well. A patent application was filed in March 1988. 


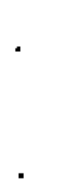




\section{EXPERIMENTAL SYSTEM AND PROCEDURES}

The system being used for experiments to develop concepts for the catalytic destruction of hazardous organic waste is centered around a $1-L$, Incone ${ }^{\circledR}$, bolted-closure autoclave (reactor). This section describes the system and the procedures used in the experiments.

\section{REACTOR SYSTEM}

In the reactor system, aqueous waste is converted at low temperatures $\left(300^{\circ} \mathrm{C}\right.$ to $460^{\circ} \mathrm{C}$ ) and high pressures (up to $5000 \mathrm{psig}$ ) to innocuous gases consisting primarily of $\mathrm{CH}_{4}, \mathrm{CO}_{2}$, and $\mathrm{H}_{2}$. The system is equipped with a sampling system that allows several samples to be taken throughout the period of the experiment while the reactor is maintained at reaction temperature and pressure. A drawing of the 1-L reactor is presented in Figure 2. The reactor is an autoclave, manufactured by Autoclave Engineers, and is operated with standard heating, cooling, and stirring equipment provided with the unit. The stirring baffle is not used so that a stainless steel liner can fit into the reactor. The use of the liner facilitates product recovery and reactor cleanup, and provides containment of alkali, chlorides, or other potential corrosive compounds.

The autoclave is heated by a 1.7-kW heater, which has the capability to heat the reaction environment up to $\sim 500^{\circ} \mathrm{C}$. Typical heatup time required to heat $300 \mathrm{~mL}$ of aqueous solution and catalyst to $400^{\circ} \mathrm{C}$ is about $90 \mathrm{~min}$. The aqueous fluid, reaction gases, and catalyst are rapidly mixed inside the autoclave by a magnetic-coupled stirrer. The reactor has a cooling coil that is used to cool down the reactor contents at the end of each experiment. The reactor and the majority of the experimental equipment under pressure are contained inside a 1/4-in. steel barricade (see Figure 3, a schematic of the entire system). Pressure indicators, temperature and stirrer controllers, and pressure and temperature alarms are held outside the barricade.

(B) Trademark of Huntington Alloys, Inc. 
Gas samples are taken through a body wall port in the top of the reactor. The reactor and sample removal system are operated remotely after the reactor has been batch charged. The sampling system, shown in Figure 3, employs a combination of a manually operated sampling valve and a pressure transducer on the sample loop to collect carefully controlled sample volumes. Typically, the sample loop is filled to a pressure of 50 psig.

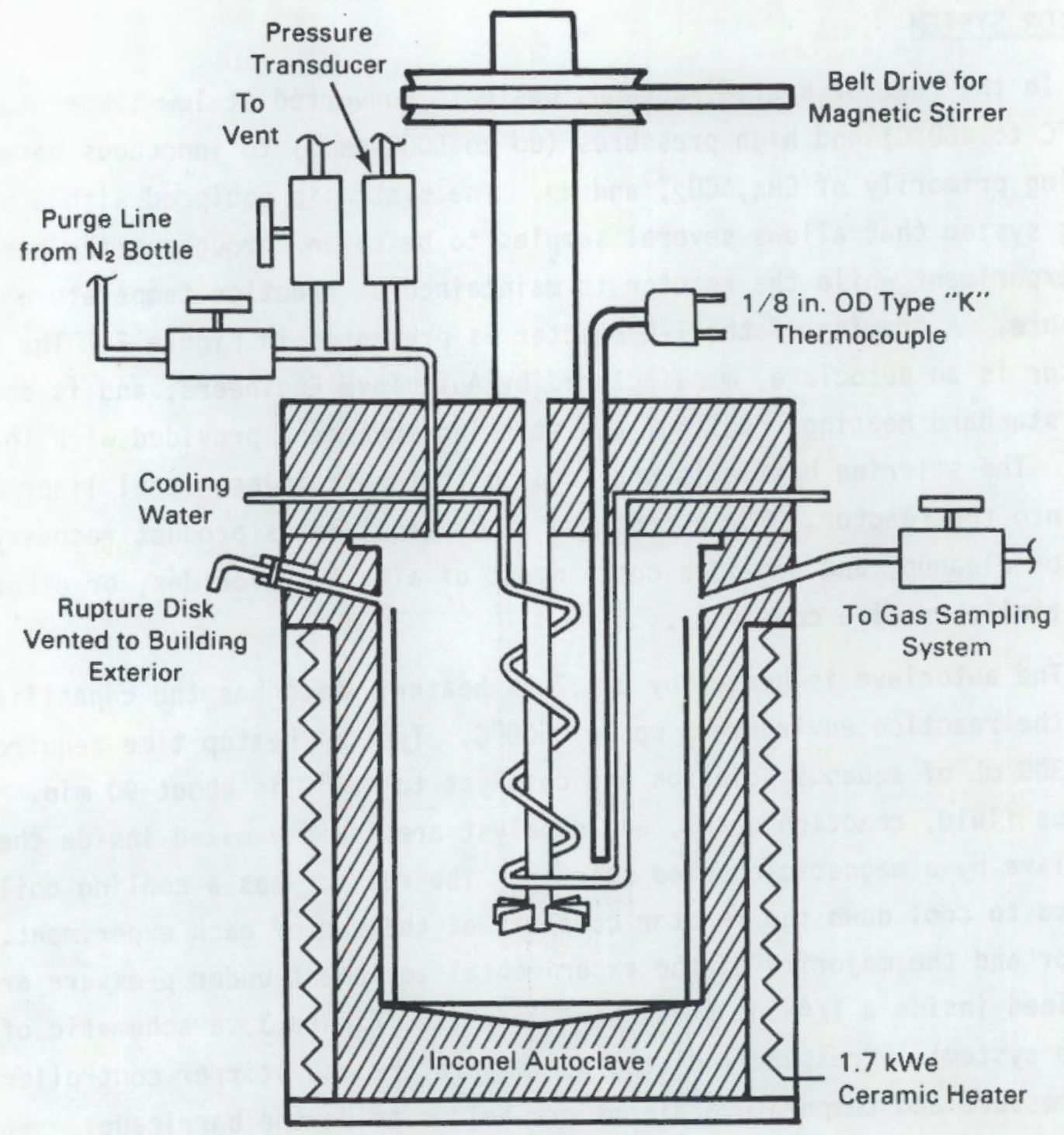

FIGURE 2. One-liter Autoclave Reactor 


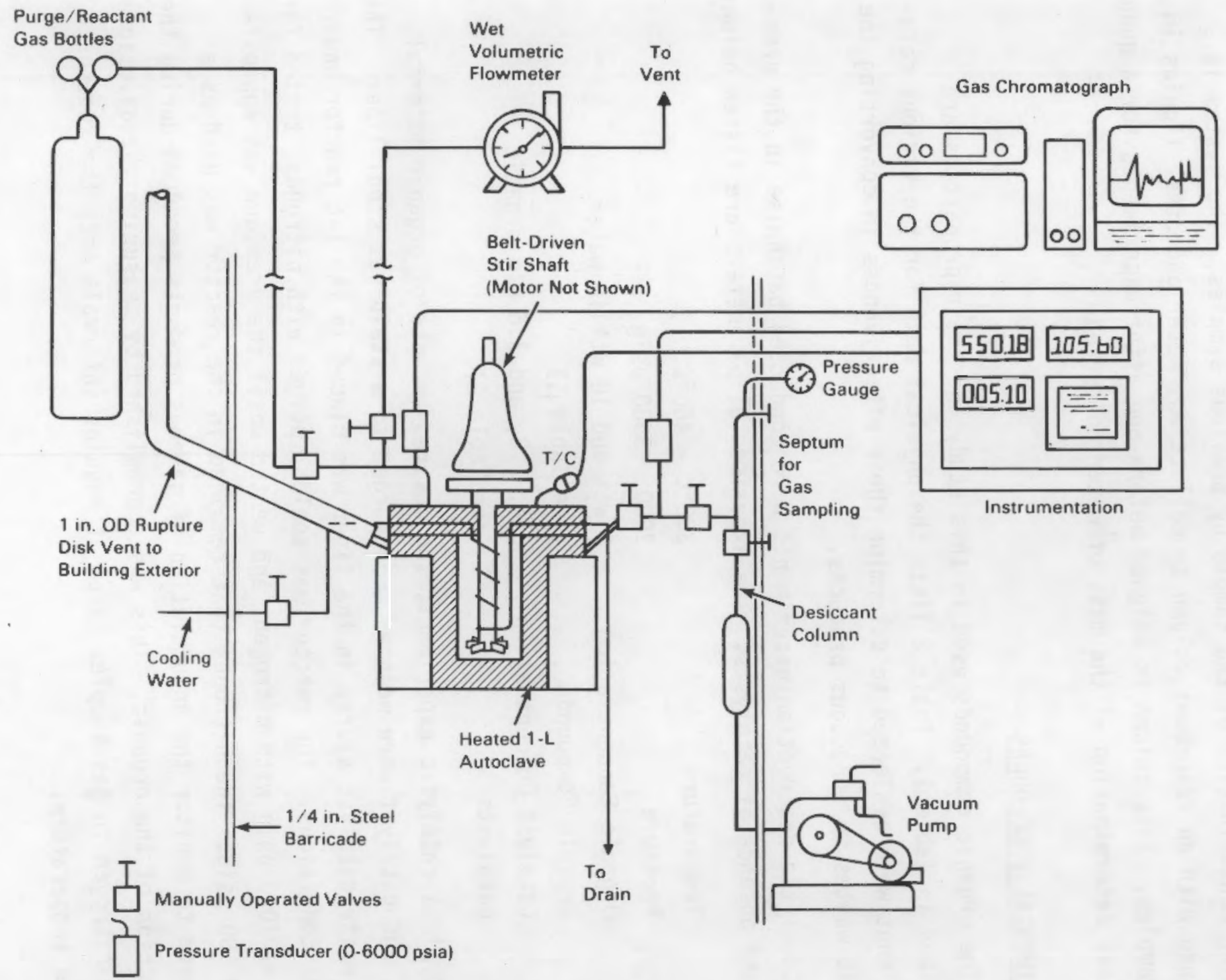

FIGURE 3. Reactor System 
The volume of the sampling system is about $3.9 \mathrm{~mL}(2.6 \mathrm{~mL}$ sample holding loop, $1.3 \mathrm{~mL}$ dead space prior to the sampling valve). The sampling system allows the entire sample loop to be evacuated prior to taking a sample, avoiding contamination of the sample by previous samples. The system is equipped with an adsorbent column to collect any water and other liquids in the samples. This column is weighed before and after experiments for a quantitative determination of the mass of water collected.

\section{EXPERIMENTAL PROCEDURES}

The organic compounds used in this study and their properties are described in Table 1. Table 2 lists the physical data for the various catalysts that were evaluated to determine their effectiveness in converting the organic wastes to innocuous products.

Catalytic destruction experiments were conducted batchwise in the presence and absence of catalysts. The experimental parameters are listed below:

$\begin{array}{ll}\text { Temperature } & 300^{\circ} \mathrm{C}-460^{\circ} \mathrm{C} \\ \text { Pressure } & 2000-5500 \mathrm{psig} \\ \text { Organic Concentration } & 2 \mathrm{wt} \% \text { and } 10 \mathrm{wt} \% \text { in water } \\ \text { Organic Compounds } & (\text { see Table 1) } \\ \text { Catalyst Concentration } & 0.4,1.2, \text { and } 3.6 \mathrm{~g} / \mathrm{g} \text { organic } \\ \text { Catalysts } & \text { (see Table 2) }\end{array}$

In a typical catalytic experiment, the desired amounts of organic material, water, and catalyst were weighed and charged to a stainless steel liner. The mixed-waste catalyst slurry in the liner was placed in the 1-L reactor under ambient conditions. The reactor was sealed, purged with nitrogen, tested for leaks at 1000 psig with nitrogen, and vented until the pressure was approximately 100 psig. The nitrogen that remained in the reactor was used as a reference to monitor the accumulation of gaseous products produced during the destruction of the organic. This was accomplished by measuring the dilution of the nitrogen in gas samples taken at regular intervals once the reactor reached temperature. 
TABLE 1. Properties of Organic Compounds Used in the Investigation

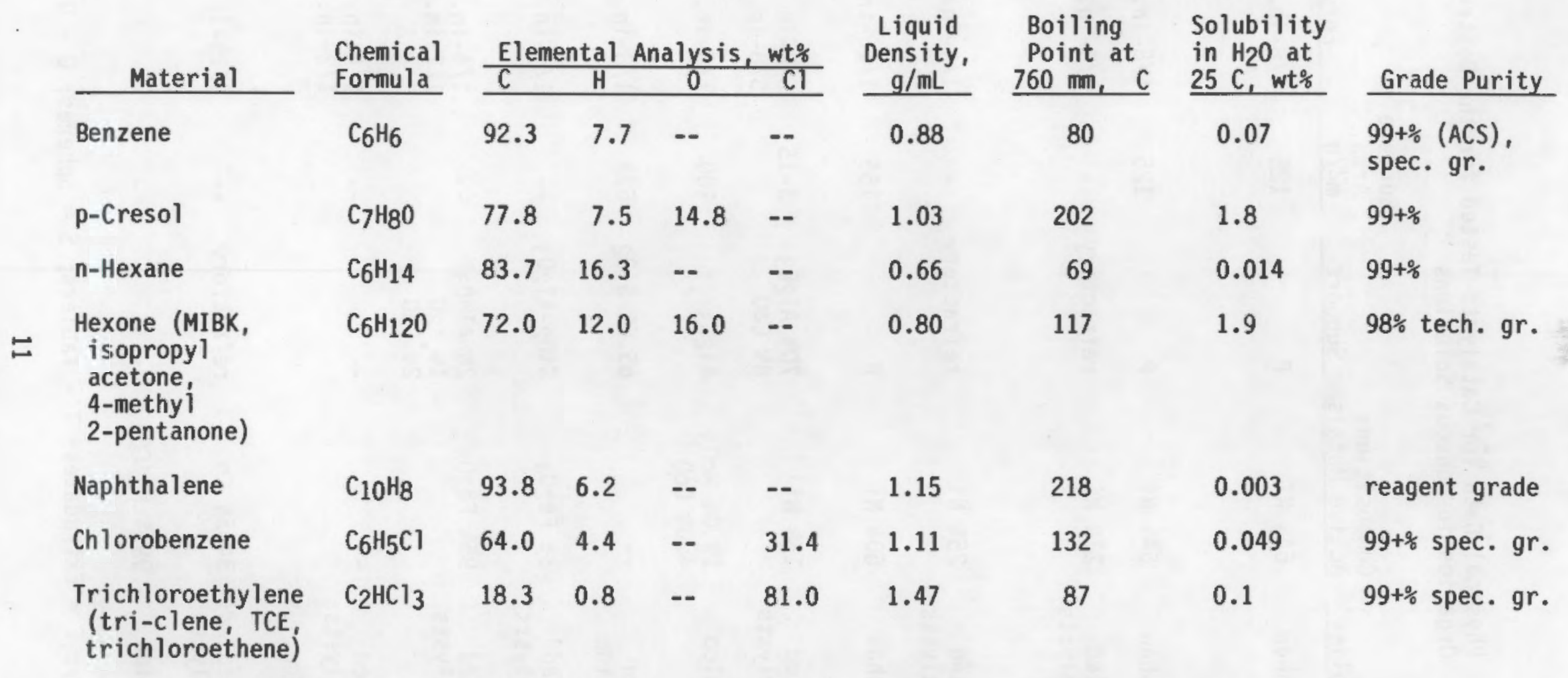


TABLE 2. Physical Data for Catalysts Tested for the Destruction of Organics in Aqueous Solutions

\begin{tabular}{|c|c|c|c|c|c|c|}
\hline $\begin{array}{c}\text { Catalyst } \\
\text { ID } \\
\end{array}$ & Supplier & $\begin{array}{l}\text { Composition: } \\
\text { Active Metals }\end{array}$ & Support & $\begin{array}{c}\text { Surface } \\
\text { Area, } \\
\mathrm{m}^{2} / \mathrm{g} \\
\end{array}$ & Form & Comments \\
\hline Ni 1404 & Harshaw & $64 \% \mathrm{Ni}$ & $P$ & 125 & 1/8-in. E & $\begin{array}{l}\text { reduced and } \\
\text { stabilized } \\
\text { version of } \\
\text { Ni } 3263\end{array}$ \\
\hline Ni 3263 & Harshaw & $64 \% \mathrm{Ni}$ & $\mathbf{P}$ & 125 & 1/8-in. E & unreduced \\
\hline G-65RS & $\begin{array}{l}\text { United } \\
\text { Catalysts }\end{array}$ & $27 \% \mathrm{Ni}$ & refractory & - & 1/4-in. $T$ & $\begin{array}{l}\text { reduced and } \\
\text { stabilized } \\
\text { version of } \\
\text { G- } 65\end{array}$ \\
\hline$G-65$ & $\begin{array}{l}\text { United } \\
\text { Catalysts }\end{array}$ & $25 \% \mathrm{Ni}$ & refractory & -- & 1/4-in. T & unreduced \\
\hline Ni 3288 & Harshaw & $60 \% \mathrm{Ni}$ & $\mathbf{P}$ & 155 & 1/16-in. E & $\begin{array}{l}\text { reduced and } \\
\text { stabilized }\end{array}$ \\
\hline$G-90 C$ & $\begin{array}{l}\text { United } \\
\text { Catalysts }\end{array}$ & $15 \% \mathrm{Ni}$ & $\begin{array}{l}70 \% \mathrm{Al}_{2} \mathrm{O}_{3} \\
8 \% \mathrm{CaO}\end{array}$ & $3-15$ & $\begin{array}{ll}5 / 8-i n . & x \\
5 / 8-i n . & R\end{array}$ & unreduced \\
\hline KAT 479 & Katalco & $\begin{array}{l}19.0 \% \mathrm{MOO}_{3} \\
4.0 \% \mathrm{COO}\end{array}$ & $\mathrm{Al}_{2} \mathrm{O}_{3}$ & 180 & 1/8-in. E & unreduced \\
\hline LZY82 & $\begin{array}{l}\text { Union } \\
\text { Carbide }\end{array}$ & -- & $65.6 \% \mathrm{SiO}_{2}$ & 625 & 1/8-in. E & -- \\
\hline$G-47$ & $\begin{array}{l}\text { United } \\
\text { Catalysts }\end{array}$ & $3 \% \mathrm{Fe}_{2} \mathrm{O}_{3}$ & $\mathrm{SiO}_{2}-\mathrm{Al}_{2} \mathrm{O}_{3}$ & -- & 1/4-in. S & unreduced \\
\hline$C-73$ & $\begin{array}{l}\text { United } \\
\text { Catalysts }\end{array}$ & $95 \% \mathrm{Fe}_{2} \mathrm{O}_{3}$ & $\begin{array}{ll}2 \% & \mathrm{Al}_{2} \mathrm{O}_{3} \\
1 \% & \mathrm{~K} 2 \mathrm{O} \\
2 \% & \mathrm{CaO}\end{array}$ & -- & $\begin{array}{l}1 / 4-i n . \\
1 / 2-i n .\end{array}$ & unreduced \\
\hline $\mathrm{C}-73 \mathrm{RS}$ & $\begin{array}{l}\text { United } \\
\text { Catalysts }\end{array}$ & -- & -- & -- & $\begin{array}{l}1 / 4-i n . \\
1 / 2-i n . \\
G\end{array}$ & $\begin{array}{l}\text { reduced and } \\
\text { stabilized } \\
\text { version of } \\
\mathrm{C}-73\end{array}$ \\
\hline G-62RS & $\begin{array}{l}\text { United } \\
\text { Catalysts }\end{array}$ & $34.5 \% \mathrm{Co}$ & refractory & -- & 3/16-in. E & reduced \\
\hline-- & Aldrich & $99+\% \quad \mathrm{~K}_{2} / \mathrm{CO}_{3}$ & -- & - & -- & in solution \\
\hline
\end{tabular}


Under normal conditions, 60 to 90 min were required to heat the reactor to the desired temperature $\left(300^{\circ} \mathrm{C}\right.$ to $\left.460^{\circ} \mathrm{C}\right)$. Gas samples were taken at regular intervals once the reactor reached the desired temperature (sampling procedure was described in the Experimental System section), and the reactor was held at the designated reaction temperature for approximately $1 \mathrm{~h}$. Pressures in the system ranged from about 2000 to 5500 psig depending on the reaction temperature selected and the amount of gas produced.

At the end of each experiment, cooling water was flushed through the internal cooling coil of the reactor and the contents brought to a temperature of $200^{\circ} \mathrm{C}$ within 5 min. After the autoclave had cooled completely, the gas product was vented and analyzed. The liquid contents of the reactor were removed and measured, and saved for later analysis.

Gaseous products were analyzed by gas chromatography using a Carle AGC-S gas chromatograph equipped for refinery gas analysis. This system analyzes for $\mathrm{H}_{2}, \mathrm{~N}_{2}, \mathrm{O}_{2}, \mathrm{CO}_{2}, \mathrm{CO}_{1} \mathrm{CH}_{4}$, and $\mathrm{C}_{2}$ hydrocarbons. Larger hydrocarbons and water are rejected in a backflush. When a large backflush was detected, the sample was also analyzed for $\mathrm{C}_{3}-\mathrm{C}_{6}$ hydrocarbons with a Carle AGC-S gas chromatograph with a flame ionization detector (FID). Both chromatographs were calibrated using standard gases.

The aqueous phase of the liquid product was analyzed directly by a gas chromatograph. The entire liquid contents of the reactor were extracted with methylene chloride and the resulting extract analyzed. In some instances where conversion was low, an organic layer could be separated and analyzed. The liquid products and the extracts were analyzed with a Hewlett Packard $5830 \mathrm{~A}$ gas chromatograph with an FID and a Hewlett Packard 18850A integrator. Standard solutions were used for calibration.

Solids, which were primarily catalyst, were filtered from the liquid contents of the reactor after the liquids were extracted with methylene chloride. The filtered solids were dried and weighed. A Perkin Elmer 240 Analyzer was used to determine the carbon content of the catalysts.

Waste conversion was determined by subtracting the weight of original organic still present in the reactor liquid product from the weight of organic material charged to the reactor. Carbon conversions to gas were 
calculated using a computer program written for the high-moisture biomass project. The amount of gas produced was based on the gas analysis using the inert nitrogen added as a tracer gas. Because of inaccuracies in this analys is procedure, carbon conversions to gas exceeded $100 \%$ in some cases. Carbon balance was based on the carbon in the organic feed material compared with the carbon in the gas, in the liquid, and on the solid catalyst. Overall material balance was based on the weight of organic, water, and catalyst charged to the reactor compared with the weight of the liquid and catalyst removed from the reactor plus the weight of the gas produced.

In the experiments with chlorinated hydrocarbons, the vent gas was scrubbed in an $8 \% \mathrm{NaOH}$ solution to remove any chlorine that might have been produced. The scrubber solution and the water remaining in the reactor liner were analyzed for $\mathrm{Cl}$ - by the specific ion electrode method using an orion Model 94-17B chloride electrode and a Corning $130 \mathrm{pH}$ meter. 


\section{EXPERIMENTAL RESULTS}

Tests were completed with a variety of organic compounds and several different types of catalysts. The organic compounds and catalysts investigated were shown previously in Tables 1 and 2. Complete results for all of the tests are included as the appendix of this report. Over 50 tests were completed as part of this investigation, and for the purpose of this discussion the runs will be referred to by number as they are in the appendix. The majority of the tests were made with hexone (methyl isobutyl ketone, MIBK), which was used as the organic material to investigate the effect of temperature, catalyst, and catalyst loading. Tests with other organic compounds were made at a standard set of conditions so they could be compared with each other and with hexone.

\section{RESULTS WITH HEXONE}

The objective of the initial testing was to define the optimal processing conditions, specifically, temperature, catalyst type, and catalyst concentration. In the previous tests with high-moisture biomass feedstocks, a combination of a reduced nickel catalyst, Ni 1404, and sodium carbonate was found to be the best catalyst system. In tests with these catalysts at $400^{\circ} \mathrm{C}, 430^{\circ} \mathrm{C}$, and $460^{\circ} \mathrm{C}$ (Runs 2 to 4 ), conversion of hexone was significantly lower than anticipated, $30 \%$ to $84 \%$, respectively. Conversion was much higher when Ni 1404 was used alone, $99.9 \%$ and $99.7 \%$ at $460^{\circ} \mathrm{C}$ and $400^{\circ} \mathrm{C}$ (Runs 5 and $6)$. For comparison, with no catalyst in the reactor, conversion of hexone was only $6.0 \%$ at $400^{\circ} \mathrm{C}$.

With $\mathrm{Ni} 1404$, hexone was converted almost entirely to gas (>99\%). Typical gas concentrations are shown in Table 3. In some of the runs with other catalysts, acetone was a significant byproduct.

\section{Catalyst Effect}

Once $\mathrm{Ni} 1404$ was established to be effective for converting hexone, several other types of catalysts were tested at $400^{\circ} \mathrm{C}$ and the same hexone concentration (10 wt\% in water) and catalyst concentration $(1.2 \mathrm{~g}$ catalyst $/ \mathrm{g}$ 
TABLE 3. Typical Composition of Gas Produced from Hexone with Reduced Nickel Catalysts at $400^{\circ} \mathrm{C}$

\begin{tabular}{lll}
\cline { 1 - 1 } Component & & Vol\% \\
\cline { 1 - 1 } $\mathrm{H}_{2}$ & & $5-13$ \\
$\mathrm{CO}_{2}$ & & $24-32$ \\
$\mathrm{CO}_{0}$ & & -- \\
$\mathrm{CH}_{4}$ & & $54-58$ \\
$\mathrm{C}_{2} \mathrm{H}_{6}$ & $<1$ \\
$\mathrm{C}_{3} \mathrm{H}_{8}$ & $1-2$ \\
$\mathrm{C}_{4} \mathrm{H}_{10}$ & $1-3$
\end{tabular}

of hexone). These results are shown in Table 4. With reduced nickel catalysts, Ni 1404, Ni 3288, and G-65 RS, hexone conversion was over 99\%. With the other catalysts the highest conversion was $23 \%$, and the results with most of the catalysts were basically the same as with no catalysts $(6 \%$ conversion). The other catalysts tested included three nickel oxide catalysts.

TABLE 4. Hexone Conversion with Different Catalysts $\left(400^{\circ} \mathrm{C}\right.$, $1.2 \mathrm{~g}$ catalyst $/ \mathrm{g}$ hexone, $10 \%$ hexone in water)

\begin{tabular}{|c|c|c|c|}
\hline Run No. & Catalyst & $\begin{array}{c}\text { Catalyst } \\
\text { Composition } \\
\end{array}$ & $\begin{array}{c}\text { Hexone } \\
\text { Conversion, wt\% }\end{array}$ \\
\hline 6 & Ni 1404 & $\mathrm{Ni} / \mathrm{Al}_{2} \mathrm{O}_{3}$ & 99.7 \\
\hline 23 & Ni 3288 & $\mathrm{Ni} / \mathrm{Al}_{2} \mathrm{O}_{3}$ & 99.6 \\
\hline 32 & G-65 RS & $\mathrm{Ni} /$ refractory & 99.4 \\
\hline 16 & KAT 479 & $\mathrm{CoMo} / \mathrm{Al}_{2} \mathrm{O}_{3}$ & 23.1 \\
\hline 51 & G-62 RS & Co/refractory & 14.9 \\
\hline 18 & G-90C & $\mathrm{Ni} / \mathrm{Al}_{2} \mathrm{O}_{3}$ & 14.6 \\
\hline 17 & LZY82 & Y-Zeolite & 13.4 \\
\hline 35 & G-65 & $\mathrm{Ni} /$ refractory & 12.2 \\
\hline 38 & Ni 3263 & $\mathrm{Ni} / \mathrm{Al}_{2} \mathrm{O}_{3}$ & 10.0 \\
\hline 11 & -- & $\mathrm{Na}_{2} \mathrm{CO}_{3}$ & 7.9 \\
\hline 34 & $C-73$ & $\mathrm{Fe}_{2} \mathrm{O}_{3}$ & 6.9 \\
\hline 25 & G-47 & $\mathrm{Fe}_{2} \mathrm{O}_{3} / \mathrm{Al}_{2} \mathrm{O}_{3}$ & 6.4 \\
\hline 36 & C-73 RS & $\mathrm{Fe}_{2} \mathrm{O}_{3}$ & 5.5 \\
\hline 10 & None & -- & 6.0 \\
\hline
\end{tabular}


Hexone conversion with these three unreduced catalysts was $10.0 \%$ to $14.6 \%$. Two other reduced and stabilized transition metal catalysts, C-73 RS containing iron and G-62 RS containing cobalt, were also ineffective.

Three different catalyst concentrations were tested with $\mathrm{Ni} 1404: 0.4$, 1.2 , and $3.6 \mathrm{~g}$ catalyst $/ \mathrm{g}$ hexone. With 1.2 and $3.6 \mathrm{~g} / \mathrm{g}$, hexone conversion was over $99 \%$ at $400^{\circ} \mathrm{C}$ (Runs 6 and 20 ). With $0.4 \mathrm{~g} / \mathrm{g}$, conversion fell to $89 \%$. Figure 4 shows carbon conversions to gas as a function of time at temperature for the three different catalyst loadings. There is little difference between $1.2 \mathrm{~g} / \mathrm{g}$ and $3.6 \mathrm{~g} / \mathrm{g}$, but the rate of conversion is significantly slower with $0.4 \mathrm{~g} / \mathrm{g}$.

A test was also conducted with G-65 RS, which contains only $27 \%$ nickel compared with $64 \%$ for $\mathrm{Ni} 1404$. Over $99 \%$ destruction was achieved in this

Preheat Temperature, ${ }^{\circ} \mathrm{C}$

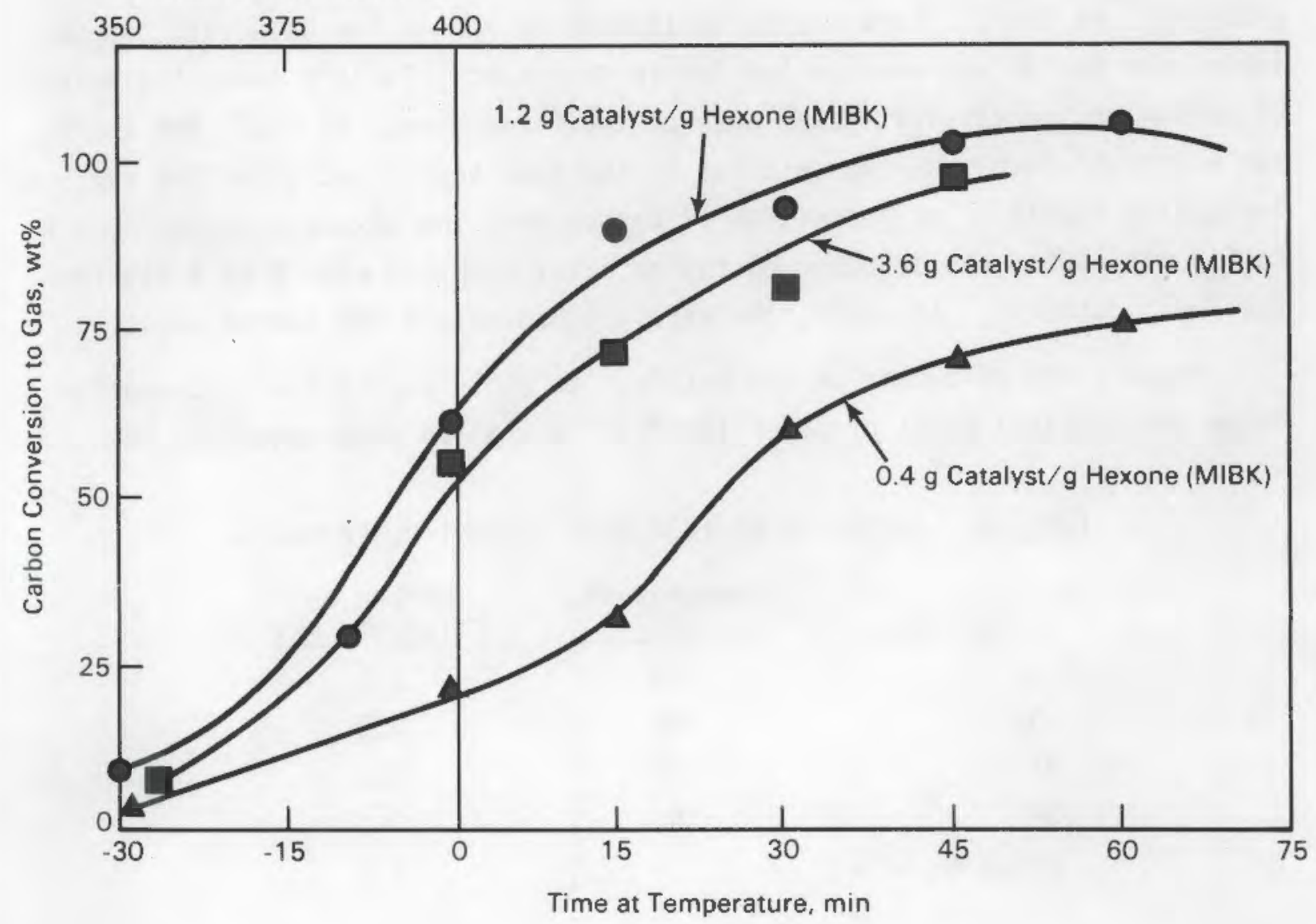

FIGURE 4. Effect of Catalyst Loading on Carbon Conversion to Gas 
test despite the lower nickel loading. These results indicate that the poor conversion with $0.4 \mathrm{~g} \mathrm{Ni} 1404 / \mathrm{g}$ hexone is not due to the reduced amount of nickel in the reactor but is more likely due to poor catalyst contacting at the reduced loading.

\section{Effect of Temperature}

The effect of temperature on hexone conversion with $\mathrm{Ni} 1404$ was evaluated over the range of $300^{\circ} \mathrm{C}$ to $460^{\circ} \mathrm{C}$ (Runs $5,6,21$, and 54). Conversion was high at the three highest temperatures tested: $99.5 \%$ at $350^{\circ} \mathrm{C}, 99.7 \%$ at $400^{\circ} \mathrm{C}$, and $99.9 \%$ at $460^{\circ} \mathrm{C}$ but fell to $96.6 \%$ at $300^{\circ} \mathrm{C}$. The results at $400^{\circ} \mathrm{C}$ and $460^{\circ} \mathrm{C}$ were very similar, but some differences were noted at $350^{\circ} \mathrm{C}$ and $300^{\circ} \mathrm{C}$. At $400^{\circ} \mathrm{C}$ and $460^{\circ} \mathrm{C}$, gas was the only product from hexone destruction. At $350^{\circ} \mathrm{C}$, conversion to gas was only $84 \%$ and at $300^{\circ} \mathrm{C}$ only $50 \%$. At $350^{\circ} \mathrm{C}$, the remainder of the carbon from the hexone was present as a solid on the catalyst. At $300^{\circ} \mathrm{C}$, there was no additional carbon on the catalyst. About $46 \%$ of the carbon was unaccounted for in this test. Table 5 shows the weight of carbon on the catalyst after each of the three runs. At $400^{\circ} \mathrm{C}$ and $460^{\circ} \mathrm{C}$, the weight of carbon on the catalyst is the same before and after the run, indicating little or no deposition of carbon from the hexone. At $350^{\circ} \mathrm{C}, 4.0$ to $5.8 \mathrm{wt} \%$ carbon was detected on the catalyst compared with 2 to $3 \mathrm{wt} \%$ for the fresh catalyst. At $300^{\circ} \mathrm{C}$, the catalyst had only $3 \mathrm{wt} \%$ carbon on it.

The buildup of carbon on the catalyst at $350^{\circ} \mathrm{C}$ may be due to operation below the critical point of water $\left(374^{\circ} \mathrm{C}\right)$. A similar phenomenon has been

TABLE 5. Carbon on $\mathrm{Ni} 1404$ Used in Tests with Hexone

\begin{tabular}{|c|c|c|}
\hline Run No. & $\begin{array}{c}\text { Temperature, } \\
{ }^{\circ} \mathrm{C}\end{array}$ & $\begin{array}{l}\text { Carbon on } \\
\text { Catalyst, wt: }\end{array}$ \\
\hline 5 & 460 & 2.1 \\
\hline 6 & 400 & 2.5 \\
\hline 21 & 350 & 5.0 \\
\hline 54 & 300 & 3.0 \\
\hline Fresh Ni 1404 & & 3.0 \\
\hline
\end{tabular}


noted by Modell, Reid, and Amin (1978). Another explanation for carbon on the catalyst is a reduced rate of conversion at $300^{\circ} \mathrm{C}$ to $350^{\circ} \mathrm{C}$. Figure 5 shows carbon conversion to gas for the four temperatures as a function of time.

This figure indicates that given enough time all of the carbon would have been converted to gas at $350^{\circ} \mathrm{C}$ and there would have been no carbon on the catalyst. However, the lack of carbon on the catalyst at $300^{\circ} \mathrm{C}$ and the poor material balance for this run do not completely substantiate this conclusion.

In the long term, carbon, if it does collect on the catalyst, may have deleterious effects on the catalyst. Long-term tests in a continuous operating unit are necessary to detemine if carbon buildup on the catalyst will be a factor. The concentration of waste (10 $\mathrm{wt} \%$ in water) was high in these tests, probably higher than typically would be found. With more dilute organic solutions, carbon buildup, it if occurred at all, would not be a

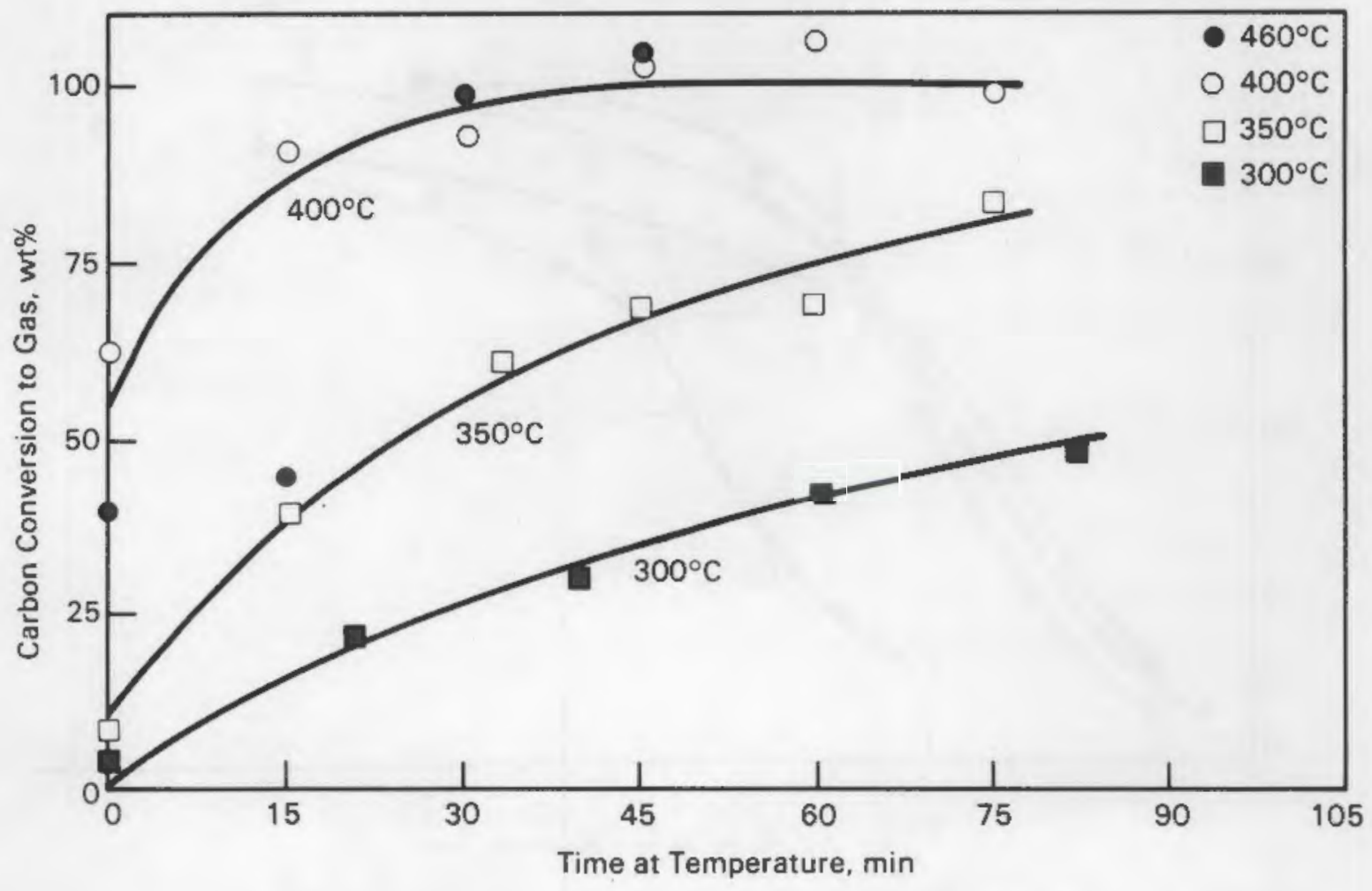

FIGURE 5. Effect of Temperature on Carbon Conversion to Gas 
serious problem. In any event, at temperatures above $400^{\circ} \mathrm{C}$, carbon buildup on the catalyst does not appear to be a problem.

\section{Effect of Organic Concentration}

Most of the tests were made at $10 \mathrm{wt} \%$ organic in water. This level, which is probably higher than typically would be encountered in an aqueous waste stream, allowed for better mass balances. Tests were made with hexone and p-cresol at 2 wt\% (Runs 14 and 15) for comparison. Catalyst concentration was kept at $1.2 \mathrm{~g} / \mathrm{g}$ of organic. Conversions were $99.9 \%$ with both compounds at the 2 wt\% level. Figure 6 shows carbon conversion to gas as a function of time. With p-cresol the $2 \mathrm{wt} \%$ solution converted more rapidly than the $10 \mathrm{wt} \%$ solution, but the hexone converted more slowly at the $2 \mathrm{wt} \%$ level. The results on the effect of organic concentration are inconclusive.

Preheat Temperature, ${ }^{\circ} \mathrm{C}$

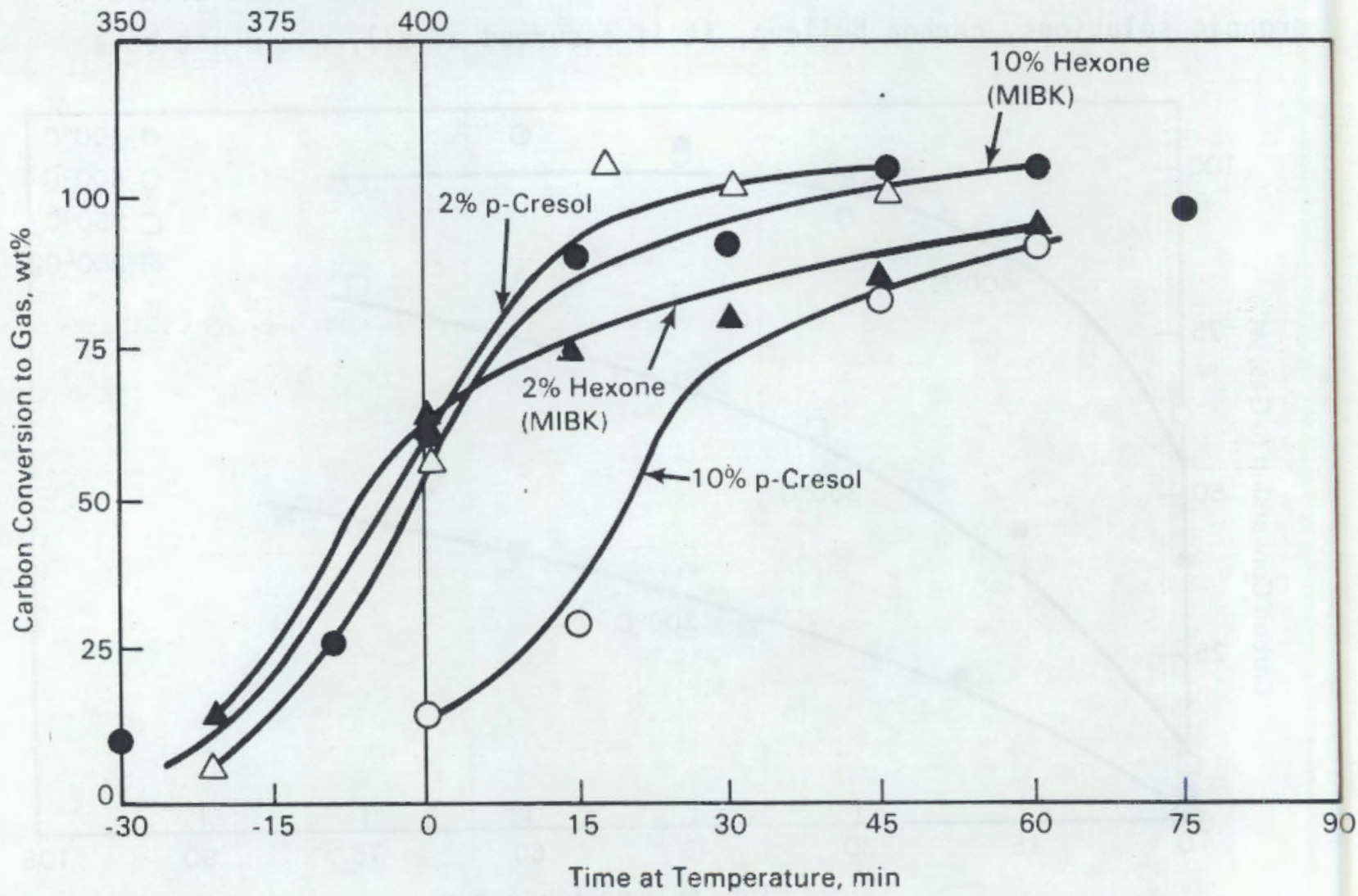

FIGURE 6. Effect of Organic Concentration on Carbon Conversion to Gas 
Tests at lower concentrations are necessary to fully define the capabilities of the concept. However, these tests will require development of improved analytical techniques.

\section{TESTS WITH OTHER HYDROCARBONS}

In addition to hexone, tests were made with four other hydrocarbons: hexane (Run 27), benzene (Run 53), p-cresol (Run 52), and naphthalene (Run 26). All of these tests were conducted at $400^{\circ} \mathrm{C}$ with $10 \mathrm{wt} \%$ organic/ water mixtures. The catalyst used was $\mathrm{Ni} 1404$ at $1.2 \mathrm{~g} / \mathrm{g}$ organic. Conversion of all of the model compounds was over $99 \%$ and in most cases approached $99.9 \%$ as shown in Table 6 .

Gas was the only product from catalytic destruction of these organics except from $p$-cresol and benzene, where small amounts of other aromatics $(0.4 \%$ to $0.8 \%$ yield) were identified in the water. The composition of the gas was similar to that produced from hexone, except little or no $C_{3}-C_{4}$ hydrocarbons were present in the gas. Figure 7 shows carbon conversion to gas for all four hydrocarbons and hexone. Hexone and hexane are converted most rapidly. Benzene, p-cresol, and naphthalene were slightly slower.

A mixed organic waste containing $2.5 \mathrm{wt} \%$ each of hexone, hexane, benzene, and naphthalene was tested at $400^{\circ} \mathrm{C}$ and $1.2 \mathrm{~g} \mathrm{Ni} 1404 / \mathrm{g}$ waste (Run 50). Conversion was over $99.6 \%$ for all of the components.

TABLE 6. Conversion of Other Hydrocarbons $\left(400^{\circ} \mathrm{C}, 1.2 \mathrm{~g} \mathrm{Ni} 1404 / \mathrm{g}\right.$ organic)

\begin{tabular}{c} 
Run No. \\
\hline 6 \\
52 \\
26 \\
27 \\
53 \\
50
\end{tabular}

\begin{tabular}{l} 
Compound \\
\hline hexone \\
p-cresol \\
naphthalene \\
hexane \\
benzene \\
hexane, hexone, benzene, \\
naphthalene mixture
\end{tabular}

Conversion, wt:\%

99.7

99.7

$99+(a)$

99.7

99.9

99.7

(a) No naphthalene was detected by the gas chromatograph (GC), but the detection limit for naphthalene is high so conversion is given as $99+\%$. 


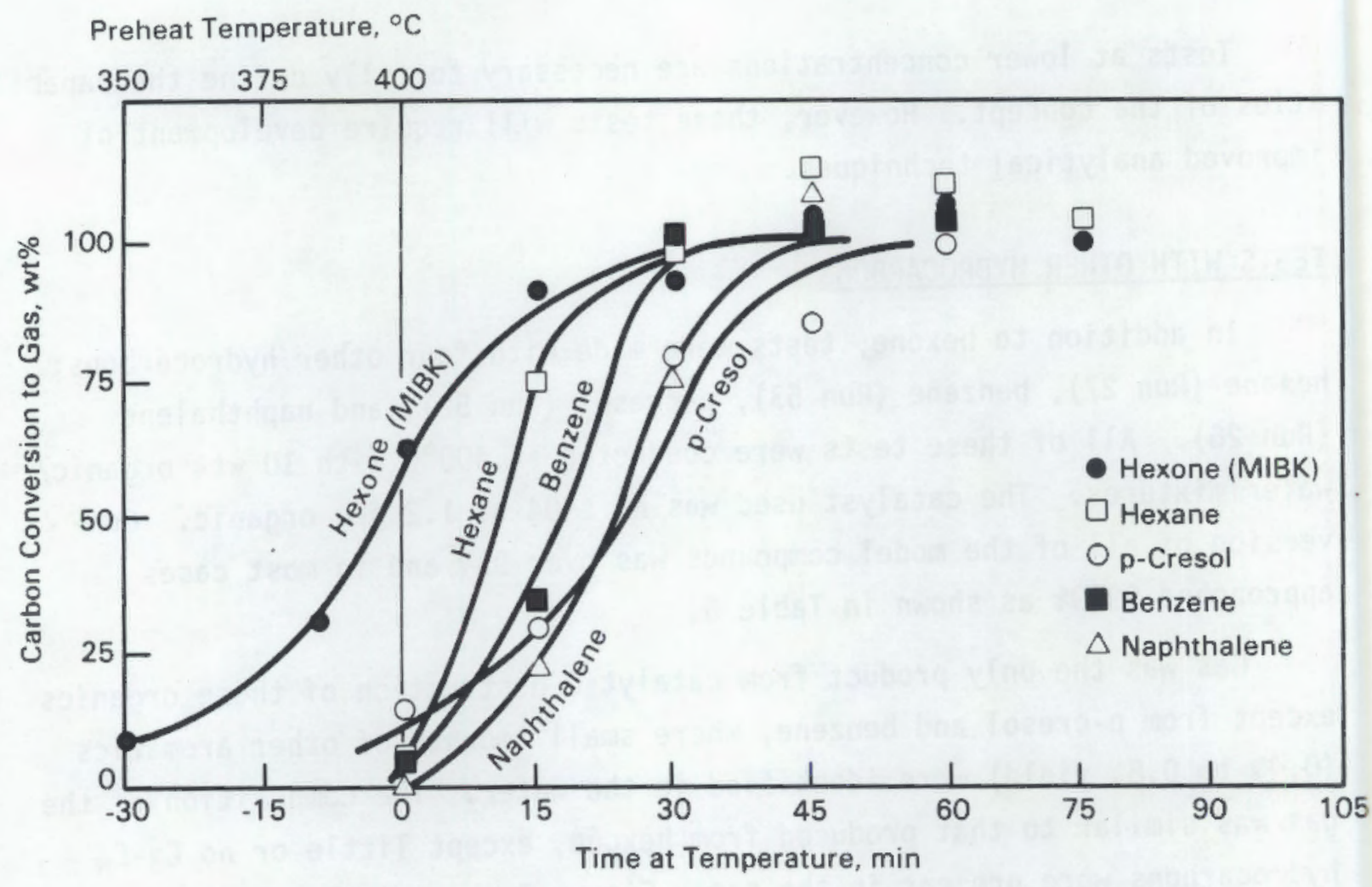

FIGURE 7. Carbon Conversion to Gas for Other Hydrocarbons

\section{RESULTS WITH CHLORINATED HYOROCARBONS}

Two chlorinated compounds, trichloroethylene (TCE) and chlorobenzene, were tested. The TCE is representative of a wide number of chlorinated solvents that are often a problem in groundwater. Chlorobenzene was used as a model compound for chlorinated aromatics such as polychlorinated biphenyls (PCBs).

Conversion of both compounds was high, typically $99 \%$ for chlorobenzene (Runs 28 to 30,33 ) and $99.9 \%$ for TCE (Run 37), at $400^{\circ} \mathrm{C}$ and about $4500 \mathrm{psig,}$ but the products were much different from those obtained from hydrocarbons. With chlorobenzene, very little gas was produced and it consisted mostly of $\mathrm{CO}_{2}$ compared with the large amount of $\mathrm{CH}_{4}$ produced from hydrocarbons. Benzene was the major product identified. With TCE, conversion to gas was higher, but because TCE is predominantly chlorine on a weight basis there is sti11 not much gas produced. In the two tests with TCE, $38 \%$ of the carbon 
was converted to gas at $350^{\circ} \mathrm{C}$ (Run 47) and $62 \%$ at $400^{\circ} \mathrm{C}$ (Run 37). The gas was primarily $\mathrm{CO}_{2}$ with a little $\mathrm{CH}_{4}$ and $\mathrm{C}_{2} \mathrm{H}_{6}$.

The initial tests with the chlorinated hydrocarbons were made using 2 wt\% solutions to limit the amount of chlorine in the reactor. With the 2 wt\% solutions, the carbon balances for both the chlorinated hydrocarbons tested were poor. With chlorobenzene, only $10 \%$ to $20 \%$ of the carbon was recovered as liquids or gases, primarily benzene. The catalyst had a large weight gain, but elemental analysis of the spent catalyst showed only $1.9 \%$ to $2.8 \%$ carbon content, which is similar to the fresh catalyst charged to the reactor (see Table 6), indicating no carbon formation on the catalyst.

Carbon recovery with TCE was better with $92 \%$ to $105 \%$ of the carbon being in the gases, liquids, or on the catalyst. About $30 \%$ of the carbon in the TCE ended up on the catalyst. Again a large weight gain was noted on the catalyst, much more than was due to the carbon.

Infrared (IR) analysis of the spent catalysts indicated the presence of $\mathrm{Ni}(\mathrm{OH})_{2}$. The formation of $\mathrm{NiCl}_{2}$, which is water soluble, was a concern but apparently did not occur. The following reaction represents what appears to occur:

$$
\mathrm{Ni}++2 \mathrm{Cl}^{-+}+\mathrm{H}_{2} \mathrm{O}+\mathrm{Ni}(\mathrm{OH})_{2}+2 \mathrm{HCl}
$$

Analysis of the liquid remaining in the reactor liner and the vent gas scrub solution indicated that all of the chlorine ends up in the water remaining in the liner and is most likely $\mathrm{HCl}$. No chlorine could be detected in the vent gas scrubber, indicating little or no formation of chlorine gas. The IR analysis of the catalyst indicated the possibility of a small amount of chlorine on the catalyst, but primarily the chlorine remained in solution.

The reactor is constructed of Inconel 600 , which has excellent resistance to chlorides at high temperatures and pressures, but corrosion is still a concern. Increased pitting was noted in the reactor body itself but is not considered a serious problem to the integrity of the reactor. In four tests (Runs 40 to 42,45 ) with high concentrations of TCE (5 to $10 \mathrm{wt} \%$ ), the Inconel rupture disk failed prematurely at pressures ranging from 3200 to 
4200 psig. These failures were apparently due to corrosion of the disk, which indicates corrosion could be a serious problem with large quantities of chlorine in the reactor. We were able to run a $5 \mathrm{wt} \%$ TCE mixture at $350^{\circ} \mathrm{C}$ (Run 47) without blowing the rupture disk. Because of the reduced temperature, the pressure was only 2900 psig.

These tests indicate that Inconel may not be the appropriate material of construction for use with chlorinated hydrocarbons in the PNL process. Processes for dechlorination (Lapierre et al. 1977) and wet air oxidation of chlorinated hydrocarbons (Sworzyn and Ackerman 1982) have used a Teflon ${ }^{*}$ lined reactor and a titanium reactor, respectively, to avoid corrosion.

The PNL catalytic destruction concept shows promise for destroying chlorinated hydrocarbons at low concentrations; however, analytical techniques need to be improved to develop a better understanding of the reaction chemistry as well as to obtain improved elemental balances. Better analytical methods are also required to operate with dilute solutions similar to actual aqueous waste streams. Furthermore, the effect the chlorinated compounds on catalyst activity needs to be understood. Obviously, chlorinated compounds have a major effect on the conversion chemistry as little or no methane is produced. In several tests with hydrocarbons made after tests with chlorinated hydrocarbons, catalyst effectiveness was lower than in previous tests. The residual chlorine in the reactor and liner apparently affected catalyst activity. Refluxing an $8 \% \mathrm{Na}_{2} \mathrm{CO}_{3}$ solution in the reactor for $48 \mathrm{~h}$ effectively decontaminated the reactor.

\section{REACTION MECHANISM}

Tests with pure organic compounds provide some information for speculation on the mechanism of conversion. One possible mechanism is complete gasification of the organics to carbon monoxide and hydrogen followed by establishment of the methanation and the water gas shift equilibrium as shown below. This equation is the accepted mechanism for high-temperature naphtha steam reforming (Rostrup-Nielsen 1984):

\footnotetext{
${ }^{-}$Trademark of E. I. duPont de Nemours and Company.
} 


$$
\begin{gathered}
\mathrm{CnHm}+\mathrm{n} \mathrm{H}_{2} \mathrm{O}+\mathrm{nCO}+(\mathrm{n}+2) \stackrel{\frac{\mathrm{M}}{\mathrm{H}_{2}}}{\mathrm{CO}+3 \mathrm{H}_{2}+\mathrm{CH}_{4}+\mathrm{H}_{2} \mathrm{O}} \\
\mathrm{CO}+\mathrm{H}_{2} \mathrm{O}+\mathrm{CO}_{2}+\mathrm{H}_{2}
\end{gathered}
$$

The hydrocarbons chemisorb on the catalyst and a carbon-carbon bond ruptures producing a surface radical. With normal paraffins, a stepwise degradation has been found in the temperature range of $250^{\circ} \mathrm{C}$ to $450^{\circ} \mathrm{C}$ with the nickel selectively attacking the ends of the chain until all of the carboncarbon bonds are broken (Rostrup-Nielsen 1975; Phillips, Mulhall, and Turner 1969). The surface radicals, which are formed when the carbon-carbon bond ruptures, react with adsorbed water to produce $\mathrm{CO}$ and $\mathrm{H}_{2}$. If this mechanism occurs in the PNL system, the CO must be rapidly hydrogenated to methane, as no $\mathrm{CO}$ has been observed in the gas at any time.

Another possibility is the direct hydrogenation of the surface radical to methane without formation of $\mathrm{CO}$. This is similar to the mechanism for hydrogenolysis (cleavage by hydrogen) of hydrocarbons (Sinfelt 1969; Sinfelt 1974). It is possible that both mechanisms contribute.

In the test with hexane, no other hydrocarbons were observed except methane, which suggests the nickel does selectively attack the ends of the chain. If the nickel attacked in the middle of the chain, C2-C4 hydrocarbons would be expected in the gas. With hexone, C3-C4 hydrocarbons and acetone were found in significant quantities, which suggests the nickel also attacks at the locations indicated below:

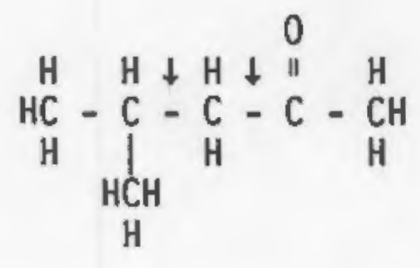

In tests at $350^{\circ} \mathrm{C}$ to $450^{\circ} \mathrm{C}$, Phillips, Mulhall, and Turner (1969) found normal paraffins to be the most reactive for steam reforming, followed by 
branched hydrocarbons and cycloparaffins, with benzene being the least reactive. As previously indicated, a similar trend was noted in the PNL studies as hexane was converted most rapidly and benzene was the slowest.

In the tests with the chlorinated compounds, TCE and chlorobenzene, dechlorination appears to take place rapidly, as little or no chlorinated compounds are detected in the products. Nickel is known to catalyze dechlorination of chlorinated hydrocarbons in the presence of hydrogen at temperatures as low as $100^{\circ} \mathrm{C}$ (Lapierre et al. 1977). Based on the results here with hydrocarbons, the dechlorinated hydrocarbons should convert to methane, but do not. Instead, the primary product with the chlorinated hydrocarbons is $\mathrm{CO}_{2}$. Very little methane is formed, which indicates that the chlorine affects the chemistry that takes place on the nickel catalyst. 


\section{CONCLUSIONS AND PLAN FOR FUTURE DEVELOPMENT}

The first 6 months of testing using a 1-L batch reactor demonstrated that catalytic destruction has significant promise as a commercial method for destroying organics and chlorinated organics in aqueous streams. With hydrocarbons, conversions were $99 \%$ and often approached $99.9 \%$ at $350^{\circ} \mathrm{C}$ to $400^{\circ} \mathrm{C}$ in the presence of a reduced nickel catalyst.

In all of the tests, the reactor was held at temperature for about $1 \mathrm{~h}$. Over $90 \%$ conversion was often achieved in 15 to 20 min, based on monitoring the gas production. Catalyst loading and contacting affected the rate of reaction. Tests in a continuous feed reactor are necessary to more precisely determine the residence time requirements. Based on the batch tests, 30 min or less appears to be sufficient in most cases.

Reduced nickel catalysts were the only catalysts found to be effective. Two other transition metals (cobalt, iron), with catalytic properties similar to nickel, were both ineffective in the reduced state and as oxides.

Most of the batch testing was conducted at pressures greater than 4000 psig because the gas produced could not be vented. In a continuous system, where the gas can be vented as it is produced, the pressure can be reduced. To minimize the process energy requirements, the pressure must be high enough to minimize the amount of water converted to steam. The pressure also reduces the size of the reactor. Table 7 shows the enthalpy and specific volume of water at various conditions. Based on these results, optimal operating conditions appear to be $350^{\circ} \mathrm{C}$ to $400^{\circ} \mathrm{C}$ and 2000 to $4000 \mathrm{psig}$. The effect of pressure on reaction rate and conversion needs to be evaluated in a continuous processing unit where the gas can be vented.

Figure 8 is a flow schematic for a conceptual process based on the results to date. The aqueous organic waste is pumped to 2000 to 4000 psig and then passed through heat exchange equipment to heat the waste stream to $350^{\circ} \mathrm{C}$ to $400^{\circ} \mathrm{C}$. Most of the preheat can be provided by heat exchange with the reactor effluent. Some auxiliary heat will be necessary and may be supplied by burning the product gases. If the organic content of the waste stream is $1 \%$ or more, it will provide sufficient fuel gas to heat the 
IABLE 7. Effect of Operating Conditions on the Enthalpy and Specific Volume of Water

\begin{tabular}{|c|c|c|c|c|c|}
\hline $\begin{array}{l}\text { Tempera } \\
{ }^{\circ} \mathrm{C} \\
\end{array}$ & $\begin{array}{c}\text { ture, } \\
{ }^{O_{F}} \\
\end{array}$ & $\begin{array}{l}\text { Pressure, } \\
\text { psig } \\
\end{array}$ & Phase & $\begin{array}{l}\text { Enthalpy, } \\
\text { Btu/1b }\end{array}$ & $\begin{array}{l}\text { Specific } \\
\text { Volume, } \\
\mathrm{ft} 3 / 1 \mathrm{~b} \\
\end{array}$ \\
\hline 350 & 662 & 3000 & liquid & 700 & 0.030 \\
\hline 350 & 662 & 2000 & vapor & 1200 & 0.210 \\
\hline 400 & 752 & 4000 & $\begin{array}{l}\text { supercritical } \\
\text { fluid }\end{array}$ & 1000 & 0.050 \\
\hline 400 & 752 & 3000 & vapor & 1200 & 0.150 \\
\hline 400 & 752 & 2000 & vapor & 1290 & 0.300 \\
\hline
\end{tabular}

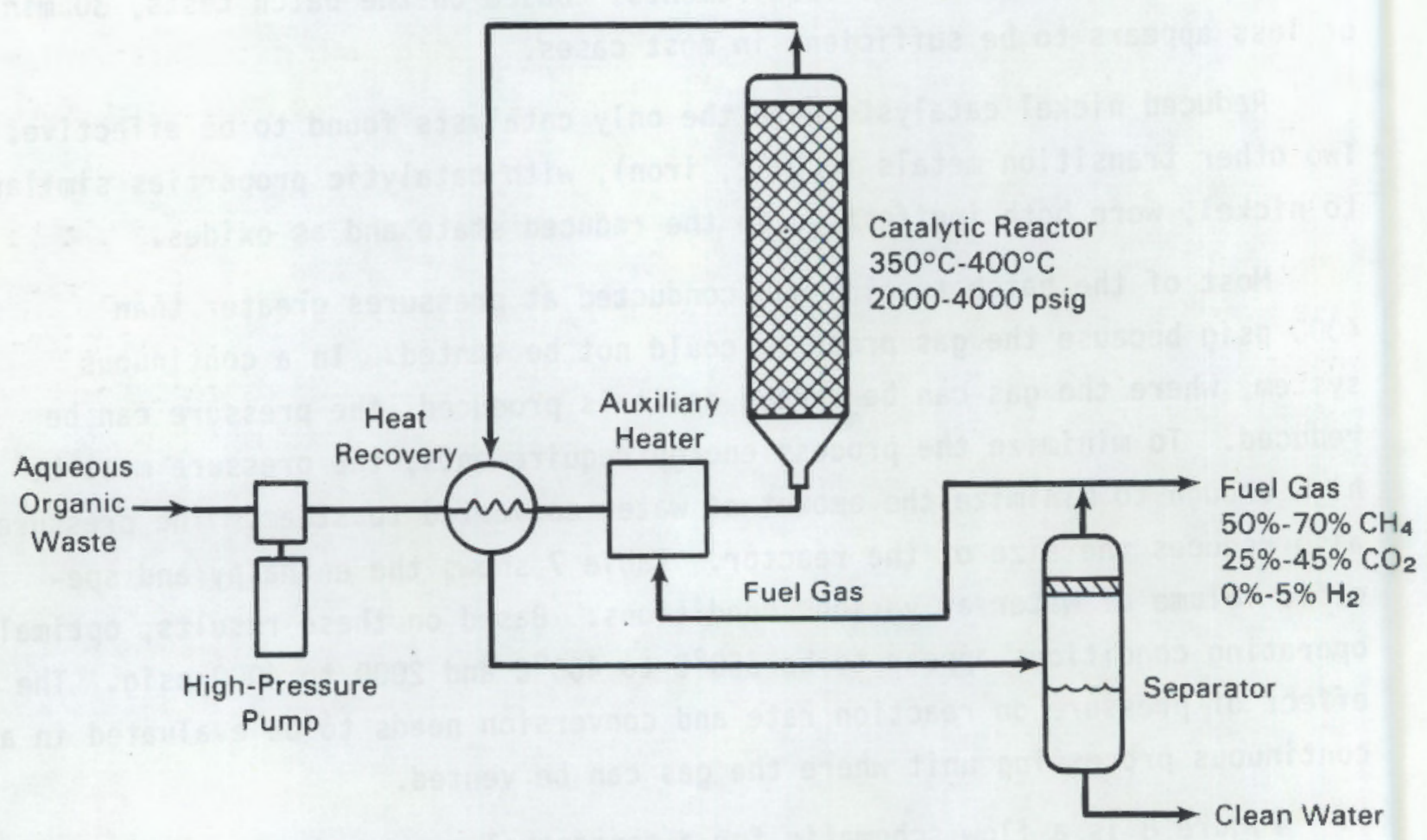

FIGURE 8. Flow Schematic of Conceptual Process

process. For concentrated organic streams, such as sludges, production of energy from the process either as natural gas, electricity, or shaft power is possible. 
Two chlorinated hydrocarbons, trichloroethylene and chlorobenzene were tested, and both were destroyed or converted to nonchlorinated organics ( $99+\%$ conversion). However, the HCl produced appears to have a detrimental effect on catalyst activity. One possibility for chlorinated hydrocarbons is a twostep process, catalytic hydrodechlorination (LaPierre et al. 1977) followed by catalytic destruction of the resulting dechlorinated hydrocarbon. Additional laboratory-scale studies are necessary to apply catalytic destruction to chlorinated hydrocarbons.

A 1-L continuous flow reactor is currently under construction in the Chemical Process Development Laboratory at PNL. This reactor will be ideal for additional development of the concept. Factors that need to be studied include the effect of pressure and residence time (space velocity) on conversion. There was no indication in the batch tests that catalyst deactivation would be a problem with hydrocarbons; however, this needs to be confimed in longer tests in the continuous reactor.

Following development in the $1-L$ continuous unit, the concept should be ready for field demonstration with hydrocarbon wastes in a small transportable unit during 1989. Development of the concept for chlorinated hydrocarbons will require further testing with the batch and continuous reactors prior to field demonstration. 



\section{REFERENCES}

Allen, C. C., and B. L. Blaney. 1985. "Techniques for Treating Hazardous Wastes to Remove Volatile Organic Constituents." Journal of the Air Pollution Control Association 35(8):841-848.

Elliott, D. C., and L. J. Sealock, Jr. 1982. "A Low-Temperature System for Gasification of Biomass Materials." U.S. Patent Application Serial No. 380,027 , May 20, 1982.

LaPierre, R. B., et al. 1977. Catalytic Conversion of Hazardous and Toxic Chemicals: Catalytic Hydrodechlorination of Polychlorinated Pesticides and Related Substances. EPA-600/3-77-018, U.S. Environmental Protection Agency, Cincinnati, Ohio.

Love, 0. T., Jr., et al. 1984. "Aeration to Remove Volatile Organic Compounds from Ground Water," second draft of interim report to the Office of Drinking Water, Office of Research and Development, U.S. Environmental Protection Agency, Cincinnati, Ohio.

Mode11, M., C. Reid, and S. I. Amin. 1978. "Gasification Process." U.S. Patent 4,113,446, September 12, 1978.

O'Brian, R. P., and R. L. Bright. 1983. "Granular Activated Carbon Treatment of Contaminated Groundwater." In Proceedings of the First Annual Hazardous Materials Management Conference, Wheaton, Illinois, July 1983.

Parmele, C. S., and R. D. Allen. 1983. "Nondestructive Regeneration of Activated Carbon as an Alternative to Air Stripping and Conventional Carbon Adsorption Systems for Ground Water Renovation." In Proceedings of the First Annual Hazardous Materials Management Conference, Wheaton, Illinois, July 1983.

Phillips, T. R., J. Mulha11, and G. E. Turner. 1969. J. Catalysis $15: 233-240$.

Rostrup-Nielsen, J. R. 1975. Steam Reforming Catalysis. Danish Technical Press Inc., Copenhagen.

Rostrup-Nielsen, J. R. 1984. Catalytic Steam Reforming. Springer-Verlag, Berlin.

Sealock, L. J., Jr., and D. C. Elliott. 1984. "Thermochemical Gasification of High-Moisture Feedstock." In Proceedings of the Sixteenth Biomass Thermochemical Conversion Contractors Meeting, NTIS \#CONF-8405157, pp. 161-176.

Shukla, H. M., and R. E. Hicks. 1984. Processes Design Manual for Stripping of Orqanics (and references therein). Office of Research and Development, U.S. Environmental Protection Agency, Cincinnati, Ohio. 
Sinfelt, J. M. 1969. Catalys is Reviews 3(2):175-205.

Sinfelt, J. M. 1974. Cat. Rev. - Sci. Eng. 9(1):174-168.

Sworzyn, E. M., and D. G. Ackerman. 1982. Interim Guidelines for the Disposal/Destruction of PCBs and PCB Items by Non-Thermal Methods. EPA600/2-82/069, U.S. Environmental Protection Agency, Research Triangle Park, North Carolina. 
APPENDIX

RUN SUMMARIES 
APPENDIX

\section{RUN SUMMARIES}

No data were obtained for the following runs:

\begin{tabular}{cl} 
Run No. & \multicolumn{1}{c}{ Cause } \\
\cline { 3 - 3 } 1 & blank, pressure check \\
8 & leaking gasket \\
40 & rupture disk failure \\
41 & rupture disk failure \\
42 & rupture disk failure \\
45 & rupture disk failure
\end{tabular}

NOTES

(a) Filtration prior to analysis resulted in large loss of organic phase. Carbon balance is poor and conversions are based on estimated losses.

(b) Sample weathered in a hood after GC analys is but before measurement of organic layer.

(c) GC showed no naphthalene remaining; however, accuracy is limited for these high boiling compounds.

(d) Sample was ruined and could not be analyzed.

(e) $50 \mathrm{psig} \mathrm{H}_{2}$ added initially.

(f) No chlorobenzene was detected; this represents the limit of detection for the gas chromatograph.

(g) $\mathrm{H}_{2}$ generated from the catalyst $\left(\mathrm{Fe}+\mathrm{H}_{2} \mathrm{O}+\mathrm{Fe}_{2} \mathrm{O}_{3}+\mathrm{H}_{2}\right)$.

(h) No TCE was detected; this represents the limit of detection.

(j) Autoclave was contaminated with chlorine from previous runs; these results are not true results with hydrocarbons.

(k) $2.5 \%$ hexone, $2.5 \%$ hexane, $2.5 \%$ benzene, $2.5 \%$ naphthalene in water. 
CATALYTIC DESTRUCTION OF HAZARDOUS WASTE

\begin{tabular}{|c|c|c|c|c|c|c|}
\hline Run \# & 2 & 3 & 4 & 5 & 6 & 7 \\
\hline Date & $3 / 23$ & $3 / 25$ & $3 / 27$ & $4 / 4$ & $4 / 8$ & $4 / 9$ \\
\hline Catalyst & $\mid \begin{array}{ll}\mathrm{Ni} & 1404+ \\
\mathrm{Na} 2 & \mathrm{CO}_{3}\end{array}$ & $\begin{array}{l}\mathrm{Ni} 1404+ \\
\mathrm{Na}_{2} \mathrm{CO}_{3}\end{array}$ & $\mid \begin{array}{ll}\mathrm{Ni} & 1404+ \\
\mathrm{Na} 2 & / \mathrm{CO}_{3}\end{array}$ & Ni 1404 & Ni 1404 & $\begin{array}{l}\mathrm{Ni} 1404+ \\
\mathrm{Na} 2 \mathrm{CO}_{3}\end{array}$ \\
\hline $\begin{array}{l}\text { Catalyst Loading, } \\
\text { g/g waste }\end{array}$ & $1.2 / 0.33$ & $1.2 / 0.33$ & $1.2 / 0.33$ & 1.2 & 1.2 & $1.2 / 0.33$ \\
\hline Temp, ${ }^{\circ} \mathrm{C}$ & 400 & 430 & 460 & 460 & 400 & 400 \\
\hline Final Press, PSIG & 5050 & 5470 & 4870 & 5240 & 5360 & 4740 \\
\hline Haste Feed & hexone & hexone & hexone & hexone & hexone & p-cresol \\
\hline Concentrations, wt\% & 10.0 & 10.0 & 10.0 & 10.0 & 10.0 & 10.0 \\
\hline Waste Conversion, wt\% & $29.9(\mathrm{a})$ & $74.4(a)$ & $84.0(a)$ & 99.9 & 99.7 & $24.0(a)$ \\
\hline $\begin{array}{l}\text { Carbon Conversion } \\
\text { to Gas, wt\% }\end{array}$ & 10.2 & 38.4 & 42.6 & 99.1 & 104 & 20.5 \\
\hline Gas Yield, mL/a waste & 231 & 726 & 1011 & 1626 & 1416 & 458 \\
\hline \multicolumn{7}{|l|}{ Gas Composition, vol\% } \\
\hline $\mathrm{H}_{2}$ & 41.0 & 39.5 & 41.8 & 12.7 & 5.1 & 31.5 \\
\hline $\mathrm{CO}_{2}$ & 44.7 & 26.9 & 25.4 & 30.8 & 29.6 & 36.0 \\
\hline $\mathrm{CH}_{4}$ & 12.0 & 27.9 & 27.1 & 54.3 & 57.8 & 29.7 \\
\hline $\mathrm{C}_{2}$ & 0.2 & 0.7 & 1.0 & 0.2 & 0.4 & 0.4 \\
\hline $\mathrm{CO}$ & $=$ & - & - & 0.5 & $=$ & 0.5 \\
\hline Backflush & 2.0 & 5.1 & 4.5 & 1.5 & 7.0 & 1.4 \\
\hline $\begin{array}{l}\text { Other Products, } \\
\text { yield, wt: } \\
\text { Acetone } \\
\text { Other Liquids }\end{array}$ & $\begin{array}{l}3.9 \\
2.0 \\
\end{array}$ & $\begin{array}{l}9.2 \\
--\end{array}$ & $\begin{array}{l}15.1 \\
--\end{array}$ & - & -- & 2.9 \\
\hline Wto Carbon on Catalyst & 5.2 & 5.2 & 3.6 & $\begin{array}{l}2.0 \\
2.3 \\
2.6 \\
\end{array}$ & $\begin{array}{l}2.2 \\
2.9\end{array}$ & 6.7 \\
\hline Mass Balance, wt\% & 99 & 100 & 98 & 96 & 100 & 97 \\
\hline Carbon Balance, wt: & $43(a)$ & $58(a)$ & $63(a)$ & 99 & 104 & $46(a)$ \\
\hline
\end{tabular}


CATALYTIC DESTRUCTION OF HAZARDOUS WASTE

\begin{tabular}{|c|c|c|c|c|c|}
\hline Run \# & 9 & 10 & 11 & 12 & 13 \\
\hline Date & $4 / 14$ & $4 / 21$ & $4 / 22$ & $4 / 23$ & $5 / 6$ \\
\hline Catalyst & $\mathrm{Ni} 1404$ & - & $\mathrm{Na}_{2} \mathrm{CO}_{3}$ & - & $\mathrm{Na}_{2} \mathrm{CO}_{3}$. \\
\hline $\begin{array}{l}\text { Catalyst Loading, } \\
\mathrm{g} / \mathrm{g} \text { waste }\end{array}$ & 1.2 & & 0.33 & & 0.33 \\
\hline Temp, ${ }^{\circ} \mathrm{C}$ & 400 & 400 & 400 & 400 & 400 \\
\hline Final Press, PSIG & 5510 & 4780 & 4810 & 4680 & 4700 \\
\hline Waste Feed & p-cresol & hexone & hexone & p-cresol & $p$-cresol \\
\hline Concentrations, wt\% & 10.0 & 10.0 & 10.0 & 10.0 & 10.0 \\
\hline Waste Conversion, wt: & 99.9 & 6.0 & 7.9 & trace & 2.1 \\
\hline $\begin{array}{l}\text { Carbon Conversion } \\
\text { to Gas, wt \% }\end{array}$ & 95.1 & 1.2 & 1.2 & trace & 0.4 \\
\hline Gas Yield, $\mathrm{mL} / \mathrm{g}$ waste & 1547 & 2.2 & 13.6 & - & 17.4 \\
\hline Gas Composition, vol\% & & & & & \\
\hline $\mathrm{H}_{2}$ & 2.7 & 20.9 & 39.4 & & 81.8 \\
\hline $\mathrm{CO}_{2}$ & 35.4 & 11.0 & 1.1 & & 1.1 \\
\hline $\mathrm{CH}_{4}$ & 61.9 & 40.7 & 42.5 & & 4.4 \\
\hline $\mathrm{C}_{2}$ & 0.1 & -- & $=$ & & 3.2 \\
\hline $\mathrm{CO}$ & - & -- & & & - \\
\hline Backflush & - & 12.1 & 17.0 & & - \\
\hline $\begin{array}{l}\text { Other Products, } \\
\text { yield, wt\% } \\
\text { Acetone } \\
\text { Other liquids } \\
\text { Toluene }\end{array}$ & $=$ & $\begin{array}{l}1.2 \\
3.5\end{array}$ & $\begin{array}{l}2.6 \\
4.1\end{array}$ & Trace & 1.7 \\
\hline Wt: Carbon on Catalyst & 3.5 & & & & 6.5 \\
\hline Mass Balance, wt\% & 96 & 100 & 100 & 100 & 98.6 \\
\hline Carbon Balance, wt\% & 95 & 88 & 90 & 106 & 108 \\
\hline
\end{tabular}


CATALYTIC DESTRUCTION OF HAZAROOUS WASTE

\begin{tabular}{|c|c|c|c|c|c|}
\hline Run \# & 14 & 15 & 16 & 17 & 18 \\
\hline Date & $5 / 5 / 87$ & $5 / 6 / 87$ & $5 / 16 / 87$ & $5 / 20 / 87$ & $5 / 21 / 87$ \\
\hline Catalyst & Ni 1404 & Ni 1404 & KAT 479 & LZY82 & G-90C \\
\hline $\begin{array}{l}\text { Catalyst Loading, } \\
\text { g/a waste }\end{array}$ & 1.2 & 1.2 & 1.2 & 1.2 & 1.2 \\
\hline Temp, ${ }^{\circ} \mathrm{C}$ & 400 & 400 & 400 & 400 & 400 \\
\hline Final Press, PSIG & 4500 & 4600 & 4400 & 4280 & 4350 \\
\hline Waste Feed & hexone & cresol & hexone & hexone & hexone \\
\hline Concentrations, wt: & 2.0 & 2.0 & 10.0 & 10.0 & 10.0 \\
\hline Waste Conversion, wt\% & 99.99 & 99.99 & 23.1 & 13.4 & 14.6 \\
\hline $\begin{array}{l}\text { Carbon Conversion } \\
\text { to Gas, wt\% }\end{array}$ & 96.8 & 100.0 & 7.2 & 2.5 & 4.8 \\
\hline Gas Yield, $\mathrm{mL} / \mathrm{g}$ waste & 1730 & 1930 & 104 & 30 & 69 \\
\hline Gas Composition, vol\% & & & & & \\
\hline $\mathrm{H}_{2}$ & 27.8 & 19.0 & 12.7 & 12.9 & 30.1 \\
\hline $\mathrm{CO}_{2}$ & 27.2 & 28.3 & 17.5 & 4.8 & 21.7 \\
\hline $\mathrm{CH}_{4}$ & 40.7 & 52.0 & 42.8 & 44.8 & 32.5 \\
\hline $\mathrm{C}_{2}$ & 0.3 & 0.2 & 0.7 & 0.3 & 0.1 \\
\hline $\mathrm{CO}$ & - & $=$ & 19.3 & 27.3 & 3.0 \\
\hline Backflush & 4.0 & 0.5 & 7.1 & 9.8 & 12.5 \\
\hline $\begin{array}{l}\text { Other Products, } \\
\text { yield, wto } \\
\text { Acetone } \\
\text { Other Liquids }\end{array}$ & & & 15.9 & $\begin{array}{r}10.3 \\
0.6 \\
\end{array}$ & 9.8 \\
\hline Wt: Carbon on Catalyst & 2.1 & 1.3 & 0.3 & 1.8 & 1.1 \\
\hline Mass Balance, wt: & 98.9 & 97.9 & 97.0 & 98.5 & 99 \\
\hline Carbon Balance, wt: & 97.2 & 100.0 & 128.1 & 96 & 81 (b) \\
\hline
\end{tabular}


CATALYIIC DESTRUCTION OF HAZARDOUS WASTE

\begin{tabular}{|c|c|c|c|c|c|c|}
\hline Run \# & 19 & 20 & 21 & 22 & 23 & 24 \\
\hline Date & $5 / 26 / 87$ & $5 / 27 / 87$ & $5 / 28 / 87$ & $5 / 29 / 87$ & $6 / 1 / 87$ & $6 / 2 / 87$ \\
\hline Catalyst & $\mathrm{Ni} 1404$ & $\mathrm{Ni} 1404$ & Ni 1404 & Ni 1404 & Ni 3288 & $\mathrm{Ni} 1404$ \\
\hline $\begin{array}{c}\text { Catalyst Loading, } \\
\mathrm{g} / \mathrm{g} \text { waste }\end{array}$ & 0.4 & 3.6 & 1.2 & 0.4 & 1.2 & 1.2 \\
\hline Temp, ${ }^{\circ} \mathrm{C}$ & 400 & 400 & 350 & 400 & 400 & 350 \\
\hline Final Press, PSIG & 5070 & 5400 & 3610 & 5290 & 5280 & 3890 \\
\hline Waste Feed & hexone & hexone & hexone & cresol & hexone & cresol \\
\hline Concentrations, wt: & 10.0 & 10.0 & 10.0 & 10.0 & 10.0 & 10.0 \\
\hline Waste Conversion, wt: & 88.9 & 99.6 & 99.5 & 99.9 & 99.5 & 99.4 \\
\hline $\begin{array}{l}\text { Carbon Conversion } \\
\text { to Gas, wt: }\end{array}$ & 77.0 & 99.4 & 83.5 & 99.4 & 99.6 & 95.0 \\
\hline Gas Yield, $\mathrm{mL} / \mathrm{g}$ waste & 1017 & 1367 & 950 & 1615 & 1257 & 1492 \\
\hline \multicolumn{7}{|l|}{ Gas Composition, vol\% } \\
\hline $\mathrm{H}_{2}$ & 8.9 & 3.8 & 3.3 & 5.6 & 5.0 & 4.2 \\
\hline $\mathrm{CO}_{2}$ & 24.2 & 32.2 & 30.2 & 35.6 & 26.9 & 46.3 \\
\hline $\mathrm{CH}_{4}$ & 56.5 & 58.7 & 49.9 & 56.6 & 57.2 & 46.6 \\
\hline $\mathrm{C}_{2}$ & 0.9 & 0.3 & 0.8 & 0.5 & 0.8 & 0.5 \\
\hline $\mathrm{CO}$ & -- & -- & $=$ & & & -- \\
\hline Backflush & 9.5 & 5.0 & 7.9 & 1.2 & 10.1 & 2.4 \\
\hline $\begin{array}{l}\text { Other Products, } \\
\text { yield, wt: }\end{array}$ & $\begin{array}{l}\text { backflush } \\
\text { isobutane } \\
\text { hexone }\end{array}$ & & & $\begin{array}{l}\text { toluene } \\
0.2 \% \\
\text { yield } \\
\end{array}$ & & $\begin{array}{l}\text { toluene } \\
\text { benzene } \\
4 \% \text { yield }\end{array}$ \\
\hline Wt: Carbon on Catalyst & 2.4 & 2.3 & 5.8 & 3.9 & 0.4 & 3.3 \\
\hline Mass Balance, wt\% & 97 & 97 & 99 & 102 & 99 & 102 \\
\hline Carbon Balance, wt\% & 88 & 100 & 92 & 100 & 100 & 100 \\
\hline
\end{tabular}

A. 5 
CATALYTIC DESTRUCTION OF HAZARDOUS WASTE

\begin{tabular}{|c|c|c|c|c|c|c|}
\hline Run \# & 25 & 26 & 27 & 28 & 29 & 30 \\
\hline Date & $6 / 3 / 87$ & $6 / 4 / 87$ & $6 / 8 / 87$ & $6 / 12 / 87$ & $6 / 15 / 87$ & $6 / 16 / 87$ \\
\hline Catalyst & G-47 & Ni 1404 & Ni 1404 & Ni 1404 & $\mid \begin{array}{ll}\mathrm{Ni} & 1404+ \\
\mathrm{Na} 2 & \mathrm{CO}_{3}\end{array}$ & Ni 1404 \\
\hline $\begin{array}{l}\text { Catalyst Loading } \\
\text { g/g waste }\end{array}$ & 1.2 & 1.2 & 1.2 & 1.2 & $1.2 / 0.32$ & 3.6 \\
\hline Temp, ${ }^{\circ} \mathrm{C}$ & 400 & 390 & 400 & 400 & 400 & 400 \\
\hline Final Press, PSIG & 4330 & 5460 & 5410 & 4610 & 4640 & 4720 \\
\hline Waste Feed & hexone & naphthalene & hexane & $\begin{array}{l}\text { chloro- } \\
\text { benzene }\end{array}$ & $\begin{array}{l}\text { chloro- } \\
\text { benzene }\end{array}$ & $\begin{array}{l}\text { chloro- } \\
\text { benzene }\end{array}$ \\
\hline Concentrations, wt $\%$ & 10.0 & 10.0 & 10.0 & 2.0 & 2.0 & 2.0 \\
\hline Waste Conversion, wt\% & 6.4 & $99+(c)$ & 99.7 & 97.8 & 98.9 & 98.7 \\
\hline $\begin{array}{l}\text { Carbon Conversion } \\
\text { to Gas, wt \% }\end{array}$ & 3.6 & 97.0 & 103.0 & 2.4 & 7.5 & 5.2 \\
\hline Gas Yield, $\mathrm{mL} / \mathrm{g}$ waste & 773 & 1893 & 1829 & 48 & 247 & 36 \\
\hline $\begin{array}{l}\text { Gas Composition, vol\% } \\
\mathrm{H}_{2}\end{array}$ & 29.1 & 2.2 & 3.7 & 43.2 & 11.2 & 11.0 \\
\hline $\mathrm{CO}_{2}$ & 24.4 & 38.3 & 23.2 & 51.4 & 74.6 & 87.0 \\
\hline $\mathrm{CH}_{4}$ & 18.7 & 59.5 & 72.9 & 5.4 & 3.9 & 2.0 \\
\hline$c_{2}$ & 0.4 & - & 0.2 & - & -- & $\ldots$ \\
\hline $\mathrm{CO}$ & 2.2 & $\because$ & - & -- & -- & -- \\
\hline Backflush & 25.3 & 0.0 & - & 5.6 & 10.2 & 0.0 \\
\hline $\begin{array}{c}\text { 0ther Products, } \\
\text { yield, wto }\end{array}$ & $\begin{array}{c}\text { acetone } \\
2.8 \% \\
\end{array}$ & & & benzene & benzene & benzenc \\
\hline$W t \%$ Carbon on Catalyst & 0.0 & 3.4 & 2.6 & 1.9 & 2.8 & 2.4 \\
\hline Mass Balance, wt\% & 99 & 99 & 101 & 96 & 99 & 99 \\
\hline Carbon Balance, wt: & 93 & $97+$ (c) & 103 & (d) & 18 & 17 \\
\hline
\end{tabular}


CATALYTIC DESTRUCTION OF HAZARDOUS WASTE

\begin{tabular}{|c|c|c|c|c|c|c|}
\hline Run \# & $31(j)$ & 32 & 33 & 34 & 35 & 36 \\
\hline Date & $6 / 17 / 87$ & $6 / 19 / 87$ & $6 / 25 / 87$ & $6 / 29 / 87$ & $7 / 16 / 87$ & $7 / 21 / 87$ \\
\hline Catalyst & $\mathrm{Ni} 1404$ & $G-65 B R / S$ & $\mathrm{Ni} 1404$ & $C-73$ & $G-65$ & $\mathrm{C}-73 \mathrm{R} / \mathrm{S}$ \\
\hline $\begin{array}{l}\text { Catalyst Loading, } \\
\mathrm{g} / \mathrm{g} \text { waste }\end{array}$ & 1.2 & 1.2 & 3.6 & 1.2 & 1.2 & 1.2 \\
\hline Temp, ${ }^{\circ} \mathrm{C}$ & 400 & 400 & 400 & 400 & 400 & 400 \\
\hline Final Press, PSIG & 5230 & 5250 & 4900 & 4360 & 4500 & 4680 \\
\hline Waste Feed & benzene & hexone & $\begin{array}{l}\text { chloro- } \\
\text { benzene }\end{array}$ & hexone & hexone & hexone \\
\hline Concentrations, wt\% & 10.0 & 10.0 & 2.0 & 10.0 & 10.0 & 10.0 \\
\hline Waste Conversion, wt: & 90.0 & 99.4 & $99.9+(f)$ & 6.9 & 12.2 & 5.5 \\
\hline $\begin{array}{l}\text { Carbon Conversion } \\
\text { to Gas, wt: }\end{array}$ & 84.8 & 108.0 & 5.5 & 1.8 & 6.0 & $\cdots$ \\
\hline Gas Yield, $\mathrm{mL} / \mathrm{g}$ waste & 1610 & 1409 & 71 & 37 & 89 & $454(g)$ \\
\hline $\begin{array}{l}\text { Gas Composition, vol\% } \\
\mathrm{H}_{2}\end{array}$ & 3.9 & 5.6 & $80.7(\mathrm{e})$ & 67.7 & 25.5 & $99.5(\mathrm{~g})$ \\
\hline $\mathrm{CO}_{2}$ & 7.2 & 30.0 & 18.2 & 6.4 & 32.2 & $=-$ \\
\hline $\mathrm{CH}_{4}$ & 7.4 & 55.2 & 1.1 & 19.6 & 27.3 & 0.5 \\
\hline $\mathrm{C}_{2}$ & 0.4 & 0.5 & -- & 0.2 & 0.1 & - \\
\hline $\mathrm{CO}$ & 0.0 & 0.8 & - & - & - & - \\
\hline Backflush & 1.0 & 8.7 & - & 6.1 & 24.0 & $=$ \\
\hline $\begin{array}{l}\text { Other Products, } \\
\text { yield, wt\% }\end{array}$ & $\begin{array}{l}\text { wt: } \\
\text { trace } \\
\text { toluene }\end{array}$ & $\begin{array}{l}\text { backf lush } \\
\text { C4 }_{4}\end{array}$ & $\begin{array}{c}\text { benzene } \\
3.9 \%\end{array}$ & $\begin{array}{c}\text { acetone } \\
\text { backflush } \\
\left(\mathrm{C}_{3}-\mathrm{C}_{4}\right)\end{array}$ & $\begin{array}{l}\text { acetone } \\
\mathrm{C}_{3}-\mathrm{C}_{4}\end{array}$ & \\
\hline Wt\% Carbon on Catalyst & 2.2 & 5.4 & 2.5 & 0.7 & 4.5 & 0.0 \\
\hline Mass Balance, wt\% & 102 & 101 & 99 & 97 & 97 & 99 \\
\hline Carbon Balance, wt\% & 95 & 108 & 9 & 83 & 89 & 87 \\
\hline
\end{tabular}


CATALYTIC DESTRUCTION OF HAZARDOUS WASTE

\begin{tabular}{|c|c|c|c|c|c|}
\hline Run \# & 37 & 38 & 39 & 43 & $44(j)$ \\
\hline Date & $7 / 22 / 87$ & $7 / 24 / 87$ & $7 / 27 / 87$ & $8 / 8 / 87$ & $8 / 10 / 87$ \\
\hline Catalyst & Ni 1404 & Ni 3263 & $\begin{array}{l}\mathrm{Ni} 1404 \\
\mathrm{C}-73 \mathrm{R} / \mathrm{S}\end{array}$ & $\begin{array}{l}\mathrm{Ni} 1404 \\
\mathrm{NaOH}\end{array}$ & Ni 1404 \\
\hline $\begin{array}{l}\text { Catalyst Loading, } \\
\text { g/g waste }\end{array}$ & 3.6 & 1.2 & 3.6 & $1.2 / 0.38$ & 1.2 \\
\hline Temp, ${ }^{\circ} \mathrm{C}$ & 400 & 400 & 400 & 400 & 400 \\
\hline Final Press, PSIG & 4944 & 4330 & 4820 & 4200 & 4660 \\
\hline Waste Feed & TCE & hexone & $\begin{array}{l}\text { chloro- } \\
\text { benzene }\end{array}$ & $\begin{array}{l}\text { chloro- } \\
\text { benzene }\end{array}$ & $\begin{array}{l}\text { hexone } \\
\text { cresol }\end{array}$ \\
\hline Concentrations, wt: & 2.0 & 10.0 & 2.0 & 10.0 & $5.0 / 5.0$ \\
\hline Waste Conversion, wt: & $99.9(\mathrm{~h})$ & 8.1 & $99.9(f)$ & 99.1 & 86.4 \\
\hline $\begin{array}{l}\text { Carbon Conversion } \\
\text { to Gas, wt: }\end{array}$ & 62.0 & 2.7 & 4.0 & 5.5 & 36.1 \\
\hline Gas Yield, $\mathrm{mL} / \mathrm{g}$ waste & 340 & 49 & $267(g)$ & 77 & 494 \\
\hline Gas Composition, vol\% & & & & & \\
\hline $\mathrm{H}_{2}$ & 42.6 & 25.5 & $83.1(g)$ & 8.3 & 16.9 \\
\hline $\mathrm{CO}_{2}$ & 46.5 & 31.7 & 14.1 & 89.1 & 33.0 . \\
\hline $\mathrm{CH}_{4}$ & 4.0 & 36.1 & 1.9 & 2.7 & 36.1 \\
\hline$C_{2}$ & 3.4 & $\cdots$ & -- & -- & 0.3 \\
\hline $\mathrm{CO}$ & -- & 3.0 & -- & -- & -- \\
\hline Backflush & 3.5 & 3.7 & 0.9 & -- & 13.7 \\
\hline $\begin{array}{l}\text { 0ther Products, } \\
\text { vield, wt\% }\end{array}$ & & & & $\begin{array}{r}\text { Benzene } \\
0.6 \% \\
\end{array}$ & $\begin{array}{l}\text { Benzene } \\
\text { Toluene }\end{array}$ \\
\hline Wt: Carbon on Catalyst & 3.7 & 2.7 & 2.0 & 5.5 & 3.4 \\
\hline Mass Balance, wt\% & 94 & 97 & 96 & 96.7 & 98 \\
\hline Carbon Balance, wt\% & 92 & 77 & 7.2 & 12.4 & $5 \underline{5.8}$ \\
\hline
\end{tabular}


CATALYTIC DESTRUCTION OF HAZARDOUS WASTE

\begin{tabular}{|c|c|c|c|c|c|c|}
\hline Run \# & $46(j)$ & 47 & $48(j)$ & 49 & 50 & 51 \\
\hline Date & $8 / 4 / 87$ & $8 / 15 / 87$ & $8 / 24 / 87$ & $8 / 29 / 87$ & $9 / 1 / 87$ & $9 / 8 / 87$ \\
\hline Catalyst & $\mathrm{Ni} 1404$ & Ni 1404 & Ni 1404 & Ni 1404 & Ni 1404 & $G-62 R S$ \\
\hline $\begin{array}{l}\text { Catalyst Loading, } \\
\mathrm{g} / \mathrm{g} \text { waste }\end{array}$ & 1.2 & 3.2 & 1.2 & 1.2 & 1.2 & 1.2 \\
\hline Temp, ${ }^{\circ} \mathrm{C}$ & 400 & 350 & 400 & 400 & 400 & 400 \\
\hline Final Press, PSIG & 4560 & 2900 & 4610 & 5200 & 5348 & 4450 \\
\hline Waste Feed & $\begin{array}{l}\text { mixed } \\
\text { waste }(k)\end{array}$ & TCE & hexone & hexone & \begin{tabular}{|l|} 
hexane \\
hexone \\
benzene \\
naphthalene \\
\end{tabular} & benzene \\
\hline Concentrations, wt $\%$ & 10.0 & 5.0 & 10.0 & 10.0 & $2.5 \%$ each & 10.0 \\
\hline Waste Conversion, wt $\frac{\%}{6}$ & $\begin{array}{l}56.8 \\
83.5 \\
35.4 \\
13.8 \\
\end{array}$ & $99.9+(h)$ & 74.8 & 99.8 & 99.7 & 14.9 \\
\hline $\begin{array}{l}\text { Carbon Conversion } \\
\text { to Gas, wt: }\end{array}$ & 13.1 & 37.8 & 32.9 & 89.0 & 78.1 & 62 \\
\hline Gas Yield, mL/a waste & 254 & 208 & 441 & 1090 & 1324 & $237(q)$ \\
\hline $\begin{array}{l}\text { Gas Composition, vol\% } \\
\mathrm{H}_{2}\end{array}$ & 26.5 & 44.9 & 13.1 & 5.6 & 4.9 & $69.6(9)$ \\
\hline $\mathrm{CO}_{2}$ & 37.1 & 39.9 & 33.9 & 27.2 & 29.6 & 15.7 \\
\hline $\mathrm{CH}_{4}$ & 29.1 & 3.4 & 41.3 & 54.3 & 61.3 & 9.2 \\
\hline$c_{2}$ & 0.2 & 1.5 & 0.7 & 0.7 & 0.3 & 0.3 \\
\hline $\mathrm{CO}$ & -- & 3.4 & -- & - & -- & 0.9 \\
\hline$\frac{\text { Backflush }}{0 \text { ther }}$ & 7.1 & 4.6 & 11.09 & 12.3 & 3.9 & 4.3 \\
\hline $\begin{array}{c}\text { Other Products, } \\
\text { yield, wty }\end{array}$ & $\begin{array}{c}\text { toluene } \\
\text { and other } \\
\text { hydrocarbon }\end{array}$ & & $\begin{array}{l}C_{3}, C_{4} \\
\text { hydro- } \\
\text { carbons }\end{array}$ & $\begin{array}{l}C_{3}, c_{4} \\
\text { hydro- } \\
\text { carbons }\end{array}$ & $\begin{array}{c}\text { other } \\
1 \text { iquids } \\
0.4 \% \\
\end{array}$ & $\begin{array}{l}\text { other } \\
1 \text { iquids } \\
8.6 \% \\
\end{array}$ \\
\hline Wt: Carbon on Catalyst & 6.9 & 4.1 & 2.7 & 3.7 & 5.5 & 7.2 \\
\hline Mass Balance, wt: & 96.5 & 100 & 97 & 99 & 98 & 99 \\
\hline Carbon Balance, wt\% & 71.6 & 70 & 58.8 & 89.3 & 87 & 83 \\
\hline
\end{tabular}


CATALYTIC DESTRUCTION OF HAZARDOUS WASTE

\begin{tabular}{|c|c|c|c|c|}
\hline Run \# & 52 & 53 & 54 & \\
\hline Date & $9 / 12 / 87$ & $9 / 14 / 87$ & $9 / 15 / 87$ & \\
\hline Catalyst & Ni 1404 & $\mathrm{Ni} 1404$ & $\mathrm{Ni} 1404$ & \\
\hline $\begin{array}{l}\text { Catalyst Loading, } \\
\mathrm{g} / \mathrm{g} \text { Waste }\end{array}$ & 1.2 & 1.2 & 1.2 & \\
\hline Temp, ${ }^{\circ} \mathrm{C}$ & 400 & 400 & 300 & \\
\hline Final Press, PSIG & 5340 & 5410 & 2130 & \\
\hline Waste Feed & p-cresol & benzene & hexone & \\
\hline Concentrations, wt $\%$ & 10.0 & 10.0 & 10.0 & \\
\hline \multicolumn{5}{|l|}{ Waste Conversion, wt: } \\
\hline $\begin{array}{l}\text { Carbon Conversion } \\
\text { to Gas, wt\% }\end{array}$ & 99.5 & 102 & 49.8 & \\
\hline Gas Yield, $\mathrm{ml} / \mathrm{q}$ waste & 1739 & 1929 & 622 & \\
\hline $\begin{array}{l}\text { Gas Composition, vol\% } \\
\mathrm{H}_{2}\end{array}$ & 10.4 & 2.7 & 5.2 & \\
\hline $\mathrm{CO}_{2}$ & 31.4 & 35.5 & 32.3 & \\
\hline $\mathrm{CH}_{4}$ & 57.7 & 60.6 & 54.2 & \\
\hline $\mathrm{C}_{2}$ & 0.2 & 0.3 & 0.6 & \\
\hline $\mathrm{CO}$ & - & - & - & \\
\hline Backflush & 0.4 & 0.9 & 7.8 & \\
\hline $\begin{array}{l}\text { Other Products, } \\
\text { yield, wt\% } \\
\text { Other Liquids } \\
\end{array}$ & 0.8 & 0.4 & & \\
\hline Wt: Carbon on Catalyst & 10.9 & 3.6 & 3.1 & \\
\hline Mass Balance, wt\% & 99 & 104 & 94 & \\
\hline Carbon Balance, wt: & 116 & 103 & 56 & \\
\hline
\end{tabular}




\section{DISTRIBUTION}

No. of

Copies

\section{OFFSITE}

G. H. Daly

U.S. Department of Energy DP-124/A-213

Germantown, MD 20545

S. Friedrich

Biomass Energy Technology Division

U.S. Department of Energy Forrestal Bldg (CE-321) 1000 Independence Avenue

Washington, DC 20585

C. H. George

U.S. Department of Energy DP 123/A-302

Germantown, MD 20545

S. L. Natof Waste Energy Reduction Division

U.S. Department of Energy

Forrestal Bldg (CE-141)

1000 Independence Avenue

Washington, DC 20585

J. R. Rossmeissi

Acting Director

Office of Industrial Programs

Forrestal Bldg (CE-141)

1000 Independence Avenue

Washington, DC 20585

10 DOE/Office of Scientific

Technical Information

5 N. G. Banns

Onsite 0 fsite, Inc.

2550 East Foothill Bird.

Suite 201

Pasadena, CA 91107
No. of

Copies

R. G. Coursen

U.S. Environmental Protection Agency

Region 10, ES-96

1200 Sixth Avenue

Seattle, WA 98101

C. J. Dial

Hazardous Waste Engineering Research Laboratory

U.S. Environmental Protection Agency

28 West St. Clair Street

Cincinnati, $\mathrm{OH} 45268$

J. L. Epler

Hazardous Waste Remedial Actions Program

Bldg. 9108, M/S2

P.0. Box $Y$

Oak Ridge, TN 37831

T. Eaton

Washington Department of Ecology PV-11

Olympia, WA 98504

C. E. Findley

U.S. Environmental Protection Agency

Region 10, ES-96

1200 Sixth Avenue

Seattle, WA 98101

A. Goodman

Oregon Department of Environmental Quality Remedial Action Section

811 SW 6th St.

Portland, OR 97204 
No. of

Copies

T. R. Hauser

Hazardous Waste Engineering Research Laboratory

U.S. Environmental Protection Agency

28 West St. Clair Street

Cincinnati, $\mathrm{OH} 45268$

H. Johnson

State of Montana

Office of Governor

Capitol Station

Helena, MT 59620

R. H. Lovely

Battelle Seatt le Research Center

4000 NE 41st Street

P.0. Box 5395

Seattle, WA 98105

F. T. Lubozynski

Engineering \& Services Laboratory

HQ AFESC/RDV

Tyndall AFB, FL 32403-6001

T. Miller

Oregon Department of

Environmental Quality

Remedial Action Section

811 SW 6th St.

Portland, OR 97204

C. R. Nelson

Project Manager.

Coal Chemistry

Gas Research Institute

8600 W. Bryn Wawr Avenue

Chicago, IL 60631

J. C. Parker

Hazardous Waste Remedial Actions Program

B1dg. 9108, M/S2

P.0. Box $Y$

Oak Ridge, TN 37831
No. of

Copies

J. Pereira

Process Development and Optimization

Corporate Research and Development

One Busch Place (156-1)

St. Louis, MO 63118

J. Peterson

Idaho Mining Association

IMA/ID

P.0. Box 1660

Boise, ID 83701

D. Rongenthen

Rockwell International Corp.

Bldg. 776

S.P.S.D.

P.0. Box 464

Golden, CO 80402-0464

N. E. Rothermich

B1dg. 9108, M/S2

Hazardous Waste Remedial Actions Program

P.0. Box $Y$

Oak Ridge, TN 37831

W. B. Schmidt

U.S. Environmental Protection Agency

Region 10

1200 6th Avenue

Seattle, WA 98101

J. H. Skinner

Office of Environmental Engineering and Technology

U.S. Environmental Protection Agency

RD-681

Washington, DC 20460 
No. of

Copies

R. N. Snelling

Environmental Monitoring Systems Laboratory

U.S. Environmental Protection Agency

P.0. Box 93478

Las Vegas, NV 89193-3478

R. Stanley

Washington Department of Ecology PV-11

0lympia, WA 98504

W. M. Stewart

U.S. Bureau of Mines

E. 315 Montgomery St.

Spokane, WA 99207

J. Teng

Anheuser-Busch Companies

One Busch Place (156-1)

St. Louis, MO 63118-1852

M. Werner

Washington Department of Ecology PV-11

Olympia, WA 98504

J. Wordell

U.S. Environmental Protection Agency

Federal Bldg./301 South Park

Orawer \$10096

Helena, MT 59626

\section{ONSITE}

12 DOE Richland Operations

R. B. Goranson (8)

J. J. Sutey (2)

M. W. Shupe

R. D. Izatt
No. of

Copies

7 Hestinghouse Hanford Company

M. R. Adams

L. C. Brown

K. A. Gasper

H. E. McGuire

P. S. Schaus

R. D. Wojtasek

T. B. Veneziano

72 Pacific Northwest Laboratory

J. F. Bagley

E. G. Baker (20)

W. W. Ballard

W. J. Bjorklund

W. F. Bonner

R. S. Butner

T. T. Claudson

D. W. Dragnich

D. C. Elliott

S. R. Gano

M. A. Gerber

M. J. Graham

R. T. Hallen

J. N. Hartley

K. E. Hartz

R. S. Kemper

S. S. Koegler

J. L. McEIroy

G. G. Neuenschwander

G. L. Roberts

L. J. Sealock, Jr. (20)

B. L. Steelman

T. L. Stewart

J. L. Straalsund

M. B. Triplett

R. L. Treat

P. C. Walkup

Technical Report Files (5)

Publishing Coordination (2) 
